\title{
WORLD-WIDE DIRECT USES OF GEOTHERMAL ENERGY 2000
}

\author{
John W. Lund ${ }^{1}$ and Derek H. Freeston ${ }^{2}$ \\ ${ }^{1}$ Geo-Heat Center, Oregon Institute of Technology, Klamath Falls, Oregon, USA \\ ${ }^{2}$ Geothermal Institute, University of Auckland, New Zealand
}

Keywords: direct-use, low enthalpy, spas, balneology, space heating, aquaculture, greenhouses, heat pumps, crop drying, industrial, snow melting

\begin{abstract}
The worldwide application of geothermal energy for direct utilization is reviewed. This paper attempts to update the previous survey carried out in 1995 by one of the co-authors (Freeston) and presented at the World Geothermal Congress in Florence, Italy. For each of these updates since 1975, the recording of data has been similar, but not exactly the same. As in 1995, an effort was made to quantify geothermal heat pump data and the investment in geothermal energy development. Final update papers were received from 60 countries, of which 55 reported some form of geothermal direct utilization. An estimate of the installed thermal power at the end of 1999 (1995 in brackets) from the current reports is $16,209 \mathrm{MWt}[8,660$ MWt] utilizing at least $64,416 \mathrm{~kg} / \mathrm{s}[37,050 \mathrm{~kg} / \mathrm{s}]$ of fluid, and the thermal energy used is $162,009 \mathrm{TJ} / \mathrm{yr}[112,441 \mathrm{TJ} / \mathrm{yr}]$. The distribution of the thermal energy used by category is approximately $37 \%$ for space heating, $22 \%$ for bathing and swimming pool heating, $14 \%$ for geothermal heat pumps, $12 \%$ for greenhouse heating, 7\% for aquaculture pond and raceway heating, $6 \%$ for industrial applications, less than $1 \%$ each for agricultural drying, snow melting, air conditioning and other uses. The reported data for number of wells drilled was 1,028 , work by professional over the five-year period was 3,363 pers on-years, and the total investment over the five years was 841 million US\$, indicating minimum values.
\end{abstract}

\section{INTRODUCTION}

Approximately a year in advance, forms for the update for electric and direct-use of geothermal energy were mailed to representatives in 85 countries in preparation for the World Geothermal Congress 2000 (WGC2000) in Japan. The forms, consisting of eight tables, were updated from those utilized in the 1995 survey, especially in terms of how to make the necessary calculations for installed power and energy utilized. The tables were also made available on the Internet through the Geo-Heat Center web site. These eight tables were to be completed, where applicable, and attached to the various country update papers submitted to WGC2000. Approximately 75 countries responded with abstracts, and then 65 of these with draft papers and 60 with a final paper of which 55 countries had some direct utilization of geothermal energy. Unfortunately, not all countries responded in a similar manner, as some had only limited exploration data to report, while others had difficulty obtaining temperature and flow data for the various uses. In some cases, with the help of the authors extensive knowledge and international experience, reasonable estimates were made of various uses, especially that for geothermal heat pumps, pools and resorts. We often had to refer to other publications for data to augment the country update papers. The authors plan to update and/or correct the data after WGC2000

The assumption used in the analysis were similar to that use in previous survey with the methods of calculation listed at the top of the various tables, namely:

$$
\begin{aligned}
& \text { Installed thermal power }(\mathrm{MWt})=\mathrm{m}(\mathrm{kg} / \mathrm{s}) \times(\mathrm{ti}-\mathrm{to}) \\
& \quad\left({ }^{\circ} \mathrm{C}\right) \times 0.004184 \\
& \text { Energy Used }(\mathrm{TJ} / \mathrm{yr})=\text { annual average flow rate }(\mathrm{kg} / \mathrm{s}) \\
& \mathrm{x}(\mathrm{ti}-\mathrm{to})\left({ }^{\circ} \mathrm{C}\right) \times 0.1319 \\
& \text { Capacity factor }=\mathrm{TJ} / \mathrm{yr} \times 0.03171 / \mathrm{MWt} \\
& \text { where } \mathrm{m}=\text { max. flow rate, ti }- \text { inlet temperature, and } \\
& \text { to = outlet temperature. }
\end{aligned}
$$

Both swimming pools and other aspects of balneology are included where they are identified. Heat pumps, as in 1995, are included and they make a significant contribution to the totals

\section{DATA SUMMARY}

Table 1 is a summary, by country, of the peak flow rates, capacity, annual utilization, and capacity factor, wells drilled, professional person-years and investment reported by the various authors. There are 55 countries reporting use, as compared to 28 in 1995 and 24 in 1985 . The maximum flow rate is at least $54,416 \mathrm{~kg} / \mathrm{s}$, an increase of $51.2 \%$ over 1995 , total capacity is $16,210 \mathrm{MWt}$, an $87.1 \%$ increase over 1995 , and energy utilization is $162,009 \mathrm{TJ} / \mathrm{yr}$, a $44.1 \%$ increase over 1995. These numbers correspond to an $8.61 \%$ annual compounded growth for flow rate, a $13.35 \%$ annual compounded growth for capacity, and a $7.58 \%$ annual compounded growth for utilizati on over this five-year period. Thus, it appears that the growth rate has increased in recent years, despite the low cost of fossi 1 fuels, economic down turns, and other factors. It should be noted that part of the growth from 1995 to present is due to better reporting, and includes some countries with geothermal uses that were missed in previous reports. The capacity factor is an indication of the amount of use (i.e., a capacity factor of 1.00 would indicate that the system is used at a maximum the entire year, and 0.5 would indicate using the system for 4,380 equivalent full-load hours per year). The world wide average for the capacity factor is 0.32 compared to 0.41 in 1995 .

Again, as in 1995, the countries with the largest utilization are China, Iceland and the United States, with Turkey moving into the top four, together accounting for over half (54\%) of the world's geothermal energy utilization. Austria, Canada, Sweden, Switzerland, and Turkey have produced the largest energy utilization increase in the past five years by almost doubling their use; the first four country's increase is due to geothermal heat pump installations and Turkey's due to the numerous new district heating systems brought on line. 
Table 1. Summary of direct-use data from individual countries. (blanks indicate no value reported)

\begin{tabular}{|c|c|c|c|c|c|c|c|c|}
\hline Country & $\begin{array}{l}\text { Flow } \\
\mathrm{kg} / \mathrm{s}\end{array}$ & $\begin{array}{r}\text { Capacity } \\
\mathrm{MWt}\end{array}$ & $\begin{array}{c}\text { Annual } \\
\text { TJ/yr }\end{array}$ & $\begin{array}{r}\text { Utilization } \\
\text { GWh/yr }\end{array}$ & $\begin{array}{r}\text { Capacity } \\
\text { factor }\end{array}$ & $\begin{array}{r}\text { Wells drill } \\
\text { ed }\end{array}$ & $\begin{array}{l}\text { Person- } \\
\text { years }\end{array}$ & $\begin{array}{l}\text { Funds } \\
\text { million \$ }\end{array}$ \\
\hline Algeria & 516 & 100.0 & 1,586 & 441 & 0.50 & & 27 & \\
\hline Argentina & 2,515 & 25.7 & 449 & 125 & 0.55 & 9 & 202 & 6 \\
\hline Australia & 90 & 10.4 & 294 & 82 & 0.90 & 0 & 60 & \\
\hline Austria & 210 & 255.3 & 1,609 & 447 & 0.20 & 17 & & \\
\hline Belgium & 58 & 3.9 & 107 & 30 & 0.87 & & & \\
\hline Bulgaria & 1,690 & 107.2 & 1,637 & 455 & 0.48 & & 85 & 0.13 \\
\hline Canada & & 377.6 & 1,023 & 284 & 0.09 & & & \\
\hline Caribbean Islands & & 0.1 & 1 & 0 & 0.62 & 0 & 0 & 0.3 \\
\hline Chile & & 0.4 & 7 & 2 & 0.55 & & & \\
\hline China & 12,677 & $2,814.0$ & 31,403 & 8,724 & 0.35 & & & \\
\hline Columbia & 222 & 13.3 & 266 & 74 & 0.63 & & 68 & 6.15 \\
\hline Croatia & 927 & 113.9 & 555 & 154 & 0.15 & 1 & 91 & 1.9 \\
\hline Czech Republic & & 12.5 & 128 & 36 & 0.33 & & 106 & 0.3 \\
\hline Denmark & 44 & 7.4 & 75 & 21 & 0.32 & & & \\
\hline Finland & & 80.5 & 484 & 134 & 0.19 & & & \\
\hline France & 2,793 & 326.0 & 4,895 & 1,360 & 0.48 & 1 & & \\
\hline Georgia & 894 & 250.0 & 6,307 & 1,752 & 0.80 & & & \\
\hline Germany & 371 & 397.0 & 1,568 & 436 & 0.13 & 16 & & \\
\hline Greece & 258 & 57.1 & 385 & 107 & 0.21 & 75 & 200 & \\
\hline Guatemala & & 3.4 & 107 & 30 & 1.00 & 1 & 10 & \\
\hline Honduras & 12 & 0.7 & 17 & 5 & 0.76 & & 14 & \\
\hline Hungary & 677 & 328.3 & 2,825 & 785 & 0.27 & 4 & 20 & 0.5 \\
\hline Iceland & 7,619 & $1,469.0$ & 20,170 & 5,603 & 0.44 & 241 & 250 & 90 \\
\hline India & 316 & 80.0 & 2,517 & 699 & 1.00 & 73 & 14 & \\
\hline Indonesia & & 7.3 & $\overline{43}$ & 12 & 0.19 & & & \\
\hline Israel & 1,672 & 63.3 & 1,713 & 476 & 0.86 & & & \\
\hline Italy & 1,656 & 325.8 & 3,774 & 1,048 & 0.37 & 1 & 50 & 10 \\
\hline Japan & 1,670 & 257.5 & $\overline{5,836}$ & 1,621 & 0.72 & & & \\
\hline Jordan & 574 & 153.3 & 1,540 & 428 & 0.32 & & & \\
\hline Kenya & & 1.3 & $\overline{10}$ & 3 & 0.25 & & & \\
\hline Korea & 1,054 & 51.0 & 1,077 & 299 & 0.67 & 164 & 42 & 276 \\
\hline Lithuania & $\overline{13}$ & 21.0 & 599 & 166 & 0.90 & 6 & 102 & 23.94 \\
\hline Macedonia & 761 & 81.2 & 510 & 142 & 0.20 & 1 & 55 & 15 \\
\hline Mexico & 4,367 & 164.2 & 3,919 & 1,089 & 0.76 & 0 & 20 & 0 \\
\hline Nepal & 25 & 1.1 & 22 & 6 & 0.66 & & 8 & 0.007 \\
\hline Netherlands & & 10.8 & 57 & 16 & 0.17 & & & \\
\hline New Zealand & 132 & 307.9 & $\overline{7,081}$ & 1,967 & 0.73 & 1 & 200 & 50 \\
\hline Norway & & 6.0 & 32 & 9 & 0.17 & & & \\
\hline Peru & & 2.4 & $\overline{49}$ & 14 & 0.65 & & & \\
\hline Philippines & & 1.0 & 25 & 7 & 0.79 & & & \\
\hline Poland & 242 & 68.5 & 275 & 76 & 0.13 & & 166 & 12 \\
\hline Portugal & 49 & 5.5 & 35 & 10 & 0.20 & 7 & & \\
\hline Romania & 890 & 152.4 & 2,871 & 797 & 0.60 & 14 & 181 & 24 \\
\hline Russia & 1,466 & 307.0 & 6,132 & 1,703 & 0.63 & 306 & 1043 & \\
\hline Serbia & 827 & 80.0 & 2,375 & 660 & 0.94 & 5 & 23 & \\
\hline Slovak Republic & 623 & 132.3 & 2,118 & 588 & 0.51 & 4 & 95 & 11.75 \\
\hline Slovenia & 656 & 42.0 & 705 & 196 & 0.53 & 18 & 43 & 16.08 \\
\hline Sweden & 455 & 377.0 & 4,128 & 1,147 & 0.35 & & & \\
\hline Switzerland & 120 & 547.3 & 2,386 & 663 & 0.14 & 4 & 58 & 230 \\
\hline Thailand & & 0.7 & 15 & 4 & 0.68 & & & \\
\hline Tunisia & & 19.7 & 174 & 48 & 0.28 & & & \\
\hline Turkey & 700 & 820.0 & 15,756 & 4,377 & 0.61 & 15 & 120 & 25 \\
\hline United Kingdom & 25 & 2.9 & 21 & 6 & 0.23 & & & \\
\hline United States & 4,550 & $5,366.0$ & 20,302 & 5,640 & 0.12 & 44 & 10 & 42 \\
\hline Venezuela & & 0.7 & 14 & 4 & 0.63 & & & \\
\hline SRAND TOTAL & 54,416 & $16,210.7$ & 162,009 & 45,006 & 0.32 & 1028 & 3363 & 841 \\
\hline
\end{tabular}


In 1985 , there were only 11 countries reporting an installed capacity of over $100 \mathrm{MWt}$. By 1990 this number had increased to 14 , and by 1995 to 15 . At present there are 18 countries reporting over $100 \mathrm{MWt}$ of installed capacity.

\section{CATEGORIES OF UTILIZATION}

The 1995 and 2000 data is divided in Table 2 among the following individual uses in terms of capacity and energy utilization for comparison:

Table 2. Categories of Utilization of Geothermal Energy World-Wide

\begin{tabular}{lrrrr}
\hline & \multicolumn{2}{c}{ Capacity MWt } & \multicolumn{2}{c}{ Utilization TJ/yr } \\
Category & 2000 & 1995 & 2000 & 1995 \\
& & & & \\
Geothermal & & & & \\
$\quad$ Heat Pumps: & 6,849 & 1,854 & 23,214 & 14,617 \\
$\begin{array}{l}\text { Space Heating } \\
\text { Greenhouse }\end{array}$ & 4,954 & 2,579 & 59,696 & 38,230 \\
$\quad$ Heating & 1,371 & 1,085 & 19,035 & 15,742 \\
$\begin{array}{l}\text { Aquaculture } \\
\quad \text { pond heating }\end{array}$ & 525 & 1,097 & 10,757 & 13,493 \\
$\quad$ Agricultural Drying & 69 & 67 & 954 & 1,124 \\
$\begin{array}{l}\text { Industrial Uses } \\
\text { Bathing and }\end{array}$ & 494 & 544 & 10,536 & 10,120 \\
$\quad$ Swimming & 1,796 & 1,085 & 35,892 & 15,742 \\
Cooling and Snow & & & & \\
$\quad$ Melting & 108 & 115 & 968 & 1,124 \\
Others & 43 & 238 & 957 & 2,249 \\
TOTAL & 16,209 & 8,664 & 162,009 & 112,441 \\
& & & & \\
\hline
\end{tabular}

Figure 1 presents the 2000 data in a pie-chart form in percentages. We attempted to separate individual space heating and district heating, but this was often difficult as reporters did not make this distinction. An approximate separation was made based on the authors' personal knowledge of the situation in the particular country. A preliminary estimate place $75 \%(27.6$ $\%$ of the total) of the space heating use in district heating. S now melting is the majority of the Cooling and Snow Melting Figure ( 0.52 vs. $0.08 \%$ of the total). Other, include mainly e arthquake monitoring and recuperation in China, tourism in $\mathrm{J}$ apan, and animal husbandry in Tunisia.

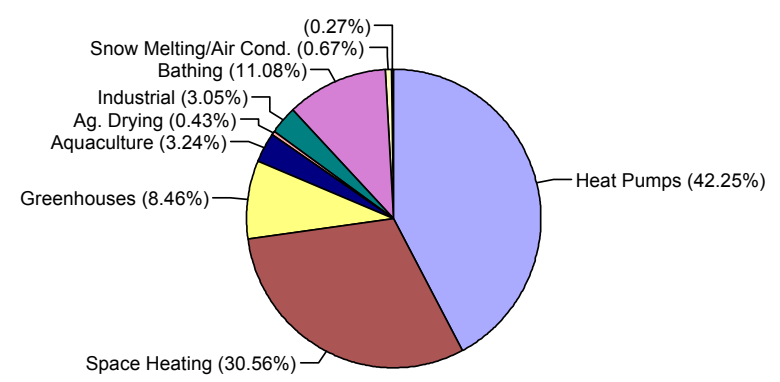

Figure 1a. Categories of Capacity in \% for 2000.

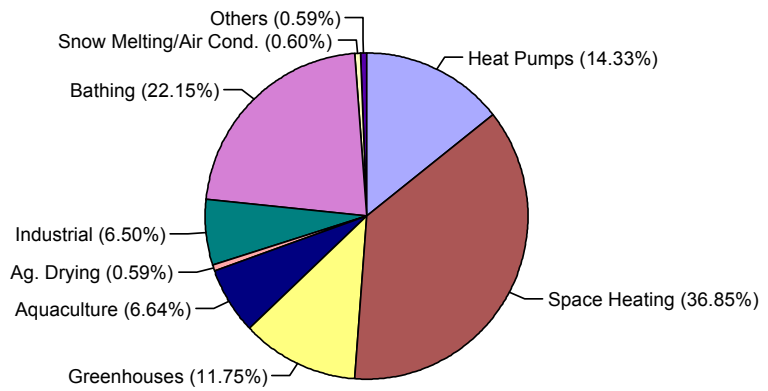

Figure 1b. Categories of Energy Use in \% for 2000.

In comparing with the 1995 data (Freeston, 1995, 1996), it is necessary to note that there is a difference in quality of the numbers and the number of countries submitting information. In fact, if one only adds the MWt for 2000 for the countries that submitted data in 1995, we get $15,450 \mathrm{MWt}$, thus the new countries have only contributed $759 \mathrm{MWt}$ or about $5 \%$ to the total. Comparing the energy, the 2000 total of the countries listed in 1995 is $150,107 \mathrm{TJ} / \mathrm{yr}$, thus the new countries add only11,902 $\mathrm{TJ} / \mathrm{yr}$ or about $7 \%$ to the 2000 total.

\section{Geothermal Heat Pumps}

Geothermal (ground source) heat pumps has had the largest growth since 1995 , almost $59 \%$ or $9.7 \%$ annually, of which almost all occurred in the United States and Europe. The installed capacity is $6,850 \mathrm{MWt}$ and the annual energy use is $23,214 \mathrm{TJ} / \mathrm{yr}$ in 26 countries. The actual number of installed units is around 500,000 , however, data is incomplete for this figure. The equivalent number of $12 \mathrm{~kW}$ units installed is slightly over 570,000 . The $12 \mathrm{~kW}$ equivalent is used as typical of homes in the United States and some western European countries. However, the size of individual units range from 5.5 $\mathrm{kW}$ (Poland and Sweden) for residential use to large units of over $150 \mathrm{~kW}$ (Germany and the United States) for commercial and institutional installations. In the United states most units are sized for the peak cooling load and are oversized for heating (except in the northern states) and thus, are estimated to average only 1,000 full-load hours per year (capacity factor of 0.11 ). In Europe, most units are sized for the heating load and are often designed to provide just the base load with peaking by fossil fuel. As a result, these units may operate from 2,000 to 6,000 full-load hours per year (capacity factor of 0.23 to 0.68 ). Unless, the actual number of full load hours were known, a value of 2,200 hours were used for energy output (TJ/yr) calculations for several of the European countries based on reporting by Rybach and Sanner (1999). The energy reported for heat pum ps was also reduced from the installed capacity based on a COP (coefficient of performance) of 3.0, which allowed for one unit of energy input (usually electricity) to three units of energy output. Thus the geothermal component is $67 \%$ of the energy output. 


\section{Lund and Freeston}

\section{Space Heating}

Space heating had the second largest growth since 1995 at slightly over $56 \%$ or $9.4 \%$ annually, reported by 28 countries. As stated earlier, about $75 \%$ of the $59,696 \mathrm{TJ} / \mathrm{yr}$ utilization is estimated for district heating, and the remainder for individual space heating. The majority of the district heating systems are in Europe where the leaders are France and Iceland, whereas the United States dominated the individual home heating systems use; typical of Klamath Falls, Oregon and Reno, Nevada. Other countries which have extensive district heating systems are China, Japan and Turkey.

\section{Greenhouse and Covered Ground Heating}

Greenhouse heating increased by $21 \%$ or $3.9 \%$ annually. The countries which have made maximum use of geothermal energy for heating greenhouses and covered ground include China, Georgia, Hungary, Iceland, Italy, Russia and the United States. The energy use ranged from 3 to $102 \mathrm{TJ} / \mathrm{yr} / \mathrm{ha}$ (Greece to Russia), with most between 13 to $27 \mathrm{TJ} / \mathrm{yr} / \mathrm{ha}$ (Slovakia to Iceland). Only 11 of 28 countries reported their heated area which totaled 322 ha. Using an average energy requirement (which is also typical of the United States) of $20 \mathrm{TJ} / \mathrm{yr} / \mathrm{ha}$ for greenhouse heating, the $19,035 \mathrm{TJ} / \mathrm{yr}$ gives about 950 equivalent ha of greenhouses being heated worldwide, since not every country gave area heated in their country report.

\section{Aquaculture Pond and Raceway Heating}

Aquaculture use of geothermal energy dropped by $20 \%$ over the five year period, however, no explanation can be give for this reduction. A total of 16 countries reported installations, with the largest use is in China, Iceland, Georgia, Israel and Turkey. Unfortunately, very little information on pond sizes, the use of raceways, or kg of fish produced were presented in the country reports. Thus, based on work in the United States, it was calculated that it requires $0.242 \mathrm{TJ} / \mathrm{yr} /$ tonne of fish (bass and Tilapia) using geothermal water in ponds and $0.675 \mathrm{TJ} / \mathrm{yr} /$ tonne of fish in raceways. Using these approximate number, the $10,757 \mathrm{TJ} / \mathrm{yr}$ of energy reported for aquaculture, should be equivalent to producing between 15,699 to 44,800 tonnes of fish per year.

\section{Agricultural Crop Drying}

Only ten countries use geothermal energy for drying various grain, vegetable and fruit crops. Examples are seaweed (Iceland), onions and garlic (United States), wheat and other cereals (Serbia), rice (Macedonia), fruit (Guatemala and Mexico), lucern or alfalfa (New Zealand), coconut meat (Philippines), and timber (New Zealand, Romania, and Mexico). However, there is a large potential and interest in using geothermal energy for drying crops in tropical regions where field spoilage occurs rapidly. A total of $954 \mathrm{TJ} / \mathrm{yr}$ are utilized in these processes, with a 15\% decrease since 1995 .

\section{Industrial Process Heat}

This is also a category that has applications in 19 countries where the installations tend to be large and energy consumpti on high. Examples include concrete curing (Guatemala and Slovenia), bottling of water and carbonated drinks (Bulgaria, Serbia and the United States), paper and vehicle parts production (Macedonia), oil recovery (Russia), milk pasteurization (Romania), leather industry (Slovenia and Serbia), chemical extraction (Bulgaria, Russia, and Poland), $\mathrm{CO}_{2}$ extraction (Iceland and Turkey), mushroom growing and laundry use (United States), salt extraction and diatomaceous earth drying (Iceland), pulp and paper processing (New Zealand), and borate and boric acid production (Italy). This use has grow approximately $4.1 \%$ over the past five years and would have been higher, except that the gold heap leaching operations in the United States were halted due to the expense of paying federal government royalties for use of water from government land.

\section{Snow Melting and Space Cooling}

There are very limited applications in this area with pavement snow melting projects in Argentina, Iceland, Japan, Switzerland and the United States. Approximately $500,000 \mathrm{~m}^{2}$ of pavements are heated, the majority in Iceland. A project in Argentina uses steam for highway snow melting in the Andes to a keep a resort community open during winter. The power required various from 130 to $180 \mathrm{~W} / \mathrm{m}^{2}$ (United States and Iceland). The only space cooling reported was in Bulgaria, Switzerland and Japan. The chiller on the Oregon Institute of Technology campus in the US has been replaced with an electric chiller due to the poor efficiency of the geothermal unit using $90^{\circ} \mathrm{C}$ water. Heat pump cooling is not included, as this process returns heat to the earth.

\section{Bathing and Swimming}

Figures for this use was the most difficult to collect and quantify. Forty-five countries have spas and resorts that have swimming pools, however, many allow the water to flow continuously, regardless of use. As a result, the actual use and capacity figures may be high. In other cases, where use was reported, but no flows and temperature drops known, a figure of $0.35 \mathrm{MWt}$ and $7.0 \mathrm{TJ} / \mathrm{yr}$, typical of many installations, were used to estimate the capacity and energy used. Use of natural hot springs that were undeveloped were not included in this report. In addition to the 45 countries that reported bathing and swimming use, the authors are also aware of developments in Armenia, Ethiopia, Malaysia, Mozambique, Yemen and Zambia, but no figures were reported from these countries since details and location were lacking. This use increased by $128 \%$ or about $18 \%$ annually, however, some of the increase is due to better reporting and including countries with long established facilities not previously reported.

\section{Other Uses}

China, Japan and Tunisia reported other uses such as earthquake monitoring, tourism, and animal husbandry.

\section{Capacity Factors}

Average capacity or load factors were determined for each country as shown in Table 1 . They vary from 0.12 to 1.00 with an average of 0.32 . The lower values are for countries dominated by geothermal heat pump use; whereas, the higher 
numbers are for countries with high industrial use or continuous operations of pools for swimming and bathing. Similar factors were also calculated for each use category and are listed in Table 3. These are then compared with the 1995 data.

Table 3. Capacity factors

\begin{tabular}{lcc}
\hline \multicolumn{1}{c}{ Category } & \multicolumn{2}{c}{ Capacity } \\
& $\mathbf{1 9 9 5}$ & $\mathbf{2 0 0 0}$ \\
& & \\
Space Heating & 0.47 & 0.38 \\
Greenhouse Heating & 0.46 & 0.44 \\
Aquaculture Ponds & 0.39 & 0.65 \\
Agriculture Drying & 0.53 & 0.44 \\
Industrial & 0.59 & 0.68 \\
Snow Melting & 0.25 & 0.29 \\
Bathing/Swimming & 0.46 & 0.63 \\
Heat Pumps & $\underline{0.25}$ & $\underline{0.11}$ \\
\multicolumn{1}{c}{ Total } & 0.41 & 0.32 \\
& & \\
\hline
\end{tabular}

Most of the values for 2000 are about the same as in 1995, except for the following: the lower space heating number is due to the dominance of values from Iceland and China: the higher aquaculture number is due to the dominance of higher values for the United Sates; and the higher number for bathing and swimming is due to more accurate reported values and the almost full-time flow through operation of many resorts; and the lower heat pump number is due to the low equivalent number of full load days used by the United States as discussed earlier. The reduction in the total factor is also due to the increased influence of geothermal heat pumps which have a low value.
Wells Drilled, Person-years, and Funds Invested in Geothermal Projects

Table 1 also shows data submitted for wells drilled, person-years of work and funds expended on direct-use project during 1995 -1999. Not all countries reported data for these tables, and it was often difficult to separate Electrical from Direct-Use values. However, for those countries that did submit data, the following observations are made. During this period over 1,028 wells were drilled with 306 in Russia and 241 in Iceland being the most active countries. Geothermal heat pump wells are not included in these data.

The person-year column numbers refer to the total employed on geothermal projects, and as was reported in Freeston (1995, 1996), it is assumed that in many countries one work force caters to both disciplines. The total number is 3,363 professional person-years of effort, submitted by 29 countries for the five-y ear period. Relating this to developed capacity is difficult because both electrical and direct-uses, with the assumption above, have benefitted from this work force. However, a percentage of the 3,363 person-years of effort enabled the capacity to increase since 1995 by $87 \%$ to $16,211 \mathrm{MWt}$. The increase of 7,547 MWt results in almost 0.5 person-years per MW of increase or about 0.2 person-year of total capacity. However, since the person-years is under reported, a better example would be data from eleven Central and Eastern European countries where almost all of the development has been in direct-use and the numbers are more complete. Here 967 person years for 1,139 MWt (180 MWt new) calculates that approximately five person-years per new MWt developed or one person-year is necessary to develop and maintain one MWt of total capacity - probably a better indication.

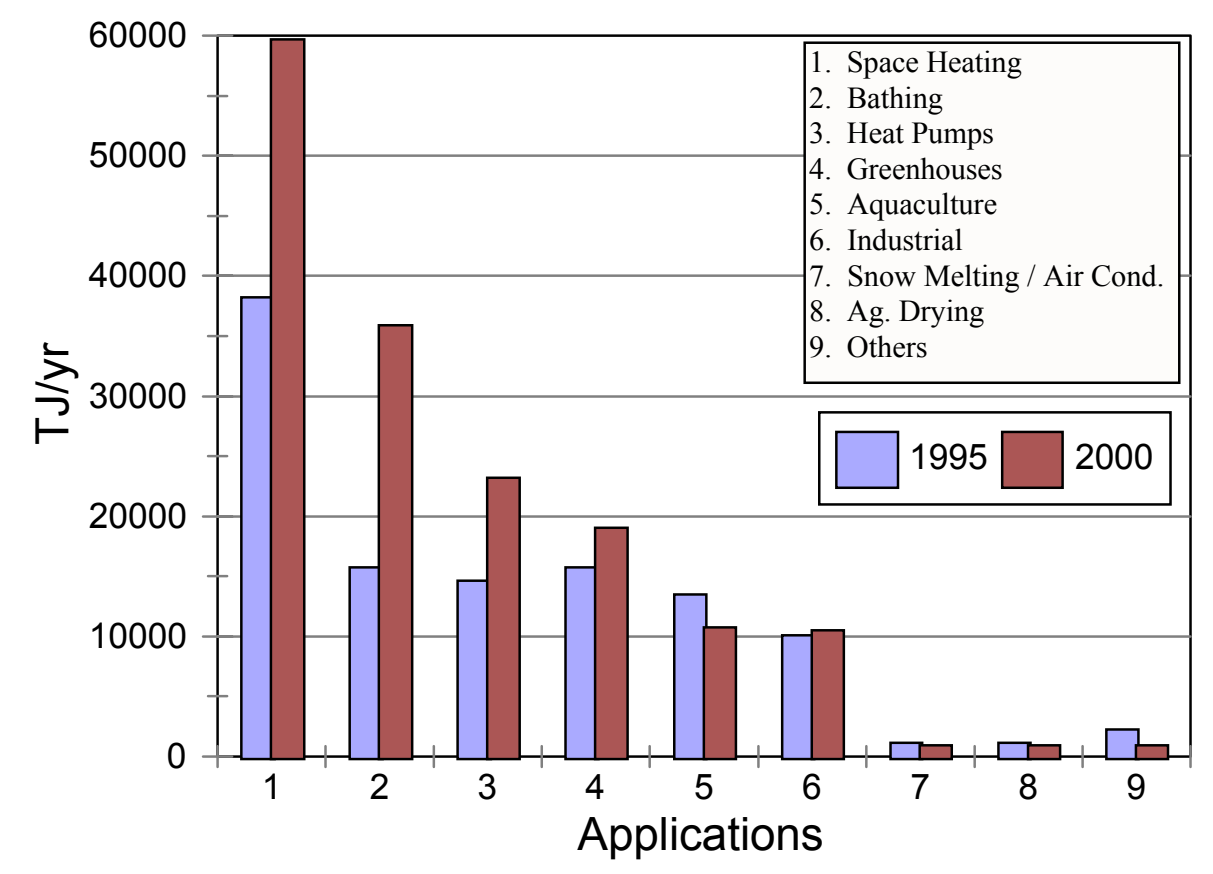

Figure 2. Comparison of Energy Use in TJ/yr for 1995 and 2000. 


\section{Lund and Freeston}

Twenty-three countries replied with data on investments. For the five-year period a total of at least US\$ 841 million was invested in direct-use development, about a $40 \%$ decrease from the 1985-1994 number. However, we are comparing a five year period to a 10 year period in this case. However, this number should not be taken too literally since only 23 countries reported data and these were not necessarily the same countries that reported in 1995. Two countries invested more than half the total: Switzerland at US\$230 million and Korea at US\$276 million. Again, to obtain a ball-park figure, if the assumptions for Central and Eastern Europe are used as above, then US\$ 105.6 million from ten countries were used to develop 180 new MWt and maintain 1,139 MWt total, thus approximately US\$ 0.6 million was used to develop one new MWt or US\$ 0.1 million to develop and maintain one MWt of total capacity.

\section{Summary}

Figure 2, presents a comparison between the various uses in 1995 and present based on Freeston $(1995,1996)$.

\section{COUNTRY REVIEWS}

The reports submitted for each country and published in the WGC2000 Proceedings of the Congress are briefly summarized below and any additional information from the recent literature added to gave an overview of the a country's development, program and prospect. Over ninety papers and personal contacts were made to gather the information as cited in the Reference section.

\section{Africa}

Algeria: Bathing and balneotherapy are the principal uses of geothermal waters in Algeria. The sites consist of modern thermal resorts, ancient roman pools and primitive shelters. Unfortunately there has been no update since 1995. At that time it was estimated by Freeston, (1995) that for a total of eleven localities used for bathing that the total flow was about $516 \mathrm{~kg} / \mathrm{s}$ and an energy annual utilization of $1586 \mathrm{TJ}$ and with an assumed load factor of 0.5 gives a thermal power of $100 \mathrm{MWt}$

Kenya: Information on the use of geothermal fluids for direct heat utilization in Kenya is scarce. However Mwangi, (2000) reports a horticultural farm using well OW-101 on the Olkaria field, with an output capacity of $1.28 \mathrm{MW}$ for use in a greenhouse for flower growing on an experimental basis which later will be converted to a commercially viable operation. This development was first mentioned at the 1995 Congress by Me laku et al., (1995) where a study had been made to utilize heat from the well to pass through a heat exchanger to produce cle an fluid to be sprayed onto the soil to sterilize it.

Tunisia: The geothermal resources of Tunisia were described in Ben Dhia and Bouri, (1995). No update report was received, however some data is available from Mohamed, (1997). This is confined to the Kebili region in the southern part of the country where geothermal fluid is used for irrigation of oasis and heating and irrigation of greenhouses. The irrigation practiced is by submersion of all the area resulting in significant water wastage. In general geothermal resources are rare and non-renewable due to the absence of recharge in aquifers which are over exploited. When the water temperature is less than $40^{\circ} \mathrm{C}$ it is used directly for irrigation but when it exceeds $45^{\circ} \mathrm{C}$ it is cooled by atmospheric towers before use, since vegetation and plants are sensitive to relatively hot water.

Other Countries: Eritrea: Lowenstern, (1996) reports of a USGS and Eritrean team assessing the geothermal potential of the Alid Volcanic center $30 \mathrm{~km}$ south of the Gulf of Zula in th e Danakil (Afar) Rift. Fumaroles and thermal pools were found in at least 11 small sites over about $10 \mathrm{~km}^{2}$. A variety of gas thermometers also yielded high parent reservoir temperatures up to and over $250^{\circ} \mathrm{C}$. Ethiopia has considerable both high and low enthalpy resources in the Ethiopian Rift Valley and Afar depression. However the only new development is utilizing wells drilled in the middle 80's at Aluto-Langano (Lakes District) where a small pilot power plant for a 5-7 MWe has been operating. There is a history however of low enthalpy use for resort and therapeutic purposes Teklemariam et al., (2000), although no details have been published. For the first time $\mathbf{M}$ orocco submitted a Country update report, Rimi, (2000) whic $\mathrm{h}$ gives an evaluation of its geothermal resources, which are mainly low enthalpy. Maps of heat flow density and temperature distributions down to $3000 \mathrm{~m}$ depth are drawn and potential regions identified by estimation of heat in place. The promising regions for development are northeastern Morocco and the sedimentary basins in the Sahara. Tanzania: Hochstein et al., (2000) reports an evaluation of the countries resources. There are at least 15 thermal areas with hot $\left(\mathrm{T}>40^{\circ} \mathrm{C}\right)$ spring activity however there appears to be little evidence to encourage or support any of these areas for development of direct use schemes. Isabirye, (2000) reports on the status of geothermal developments in Uganda. However there is no mention of direct heat applications, the studies to date appear to have focused on power generation.

\section{The Americas}

Central America and the Caribbean Islands

A number of countries in Central American and the Caribbean Islands have developed geothermal electric power. These include Costa Rica (115 MWe), El Salvador (161 MWe), Guatemala (33.4 MWe), Nicaragua (70 MWe), and Guadeloupe (5 MWe). However, as detailed below, only two countries and several Caribbean Islands report any geothermal direct-uses.

Guatemala: The first two successful direct-use of geothermal energy in Guatemala has been at the Amatitlan geothermal field (Merida, 1999). The first one is Bloteca, a construction block factory established about 20 years ago and that recently started using geothermal steam in the curing process for concrete products. The other one is Agroindustrias La Laguna, a fruit dehydration plant, that was setup as an experimental and demonstration project. While developing this second project the owners decided to bring a product, Eco-Fruit, to the local market using the plant. The product was so successful that it has been in all supermarket chains for the past two-and-a-half years. At Bloteca a $185^{\circ} \mathrm{C}$ well is used saving $\$ 24,000$ per month as compared to diesel fuel. The installed capacity is $0.88 \mathrm{MWt}$ and the annual utilization is $27.65 \mathrm{TJ}$. A downhole heat exchange $\mathrm{r}$ 
is used at the Eco-Fruit plant, with an estimated installed capacity of $0.5 \mathrm{MWt}$ and an annual utilization of $15 \mathrm{TJ}$.

Honduras: The development of geothermal resources in the electrical generating field is being changed from a state owned company to open private participation, thus new developments are on hold (Castillo and Salgado, 2000). There is direct heat utilization in the form of bathing and swimming. A total of three locations have been developed in the country with an installed capacity of $0.71 \mathrm{MWt}$ and an annual utilization of $17.02 \mathrm{TJ}$.

Nicaragua: No direct utilization exists at this time, but the government with support from the European Community and the U.N. Economic Commission for Latin America and The Caribbean (ECLAC) will carry out a geothermal rural electrification and direct application pilot project in two areas: Cosiguina and Ometepe Island (Zuniga and Medina, 2000). Low-enthalpy geothermal fluids will be investigated for use in grain drying, fish farming and heating greenhouses.

Caribbean Islands: Low temperature waters are informally used for bathing on several islands and bath houses have been built on St. Lucia and Nevis (Huttrer, 2000). Installed capacity is $0.05 \mathrm{MWt}$ and annual use is $0.97 \mathrm{TJ}$. Otherwise, geothermal fluids are not being used in this region except for the power plant on Guadeloupe.

\section{North America}

Canada: Geothermal direct utilization consists of four categories in Canada: geothermal heat pumps, aquifer thermal energy storage, energy from mine waters, and use at resorts (Allen, et al., 2000). The use of low-grade geothermal energy for heating and cooling using heat pumps, has increased steadily in recent years. Today, there is an estimated 30,000 units of 12 $\mathrm{kW}$ installed, giving a capacity of $360 \mathrm{MWt}$ and an annual use of 864 TJ. (Kane, 2000). Canada's cold winters coupled with growing concerns over greenhouse gas emissions suggests that this technology will be an important component of the country's geothermal industry in the future. The development is usually in small units, providing heat and/or cooling to commercial buildings and larger private homes. However, there are several showcase projects situated throughout the country that have proven to be economically attractive. Some of these applications have combined heat exchangers and aquifer thermal storage technologies (ATES), whereby the geothermal energy is recycled in the ground to provide both seasonal heating and cooling. ATES has been or is currently being implemented in a number of large-scale buildings projects in Canada, including in Ottawa, New Brunswick, British Columbia, and Toronto. A low-temperature geothermal resource associated with abandoned coal mines at Springhill, Nova Scotia continues to provide direct-use geothermal energy for space heating in an industrial development in that community (Jessop, 1995). This project provides $26 \mathrm{TJ} / \mathrm{yr}$ and an estimated $11 \mathrm{MWt}$ of installed capacity. A similar project has been proposed for Nanaimo, British Columbia where there is an abundance of warm water in extensive underground mine workings beneath the city. There are also 11 commercial hot pools and eight resorts in British Columbia and Alberta using geothermal energy for heating with average temperatures of $40^{\circ}$ and $50^{\circ} \mathrm{C}$ respectively (Sadler
Brown, 2000). This would add an estimated 6.6 MWt and 133 $\mathrm{TJ} / \mathrm{yr}$. The total is then $377.6 \mathrm{MWt}$ and $1023 \mathrm{TJ} / \mathrm{yr}$.

Mexico: In addition to having $755 \mathrm{MWe}$ of geothermal electric power on-line, Mexico has several smaller space heating, greenhouse heating, agricultural drying, timber drying, and mushroom breeding projects, along with 20 bathing and swimming pool heating sites (Quijano-Leon and Gutierrex-Ne grin, 2000). The agricultural drying (fruit drying), greenhous e heating, space heating and timber drying projects are demonstration facilities at the Los Azufres geothermal field ( Casimiro and Pastrana, 1996). The mushroom growing facility is located at the Los Humeros geothermal field, which produces approximately 1.5 tonnes annually of Pleurotus ostreatus (Ra ngel, 1998). An experimental timber drying facility, not reported, is located at Los Azufres, and adds and additional 0.04 MWt and $0.63 \mathrm{TJ} / \mathrm{yr}$. The total capacity of these projects is 0.23 MWt and the annual energy use is $6.04 \mathrm{TJ}$. There are many places where warm waters are used for recreation and therapeutic purposes, but there are no coordinated efforts to promote balneology. These places use from $7 \mathrm{~kg} / \mathrm{s}$ to $1,000 \mathrm{~kg} / \mathrm{s}$ in the pools, most of which are located outside. They are found throughout the Mexican volcanic zone and some were even used by the early Aztecs. The total installed capacity is $164.23 \mathrm{MWt}$ and the estimated annual energy use is 3,919.48 TJ.

United States: Since 1995, 27 new and 10 expanded direct-use projects have been developed representing $136 \mathrm{MWt}$ in thermal capacity and 2,600 TJ of annual energy utilization (Lund and Boyd, 2000). Geothermal heat pumps represent the largest growth sector during this period, adding an estimated 2,956 MWt and 3,812 TJ annually. The total capacity of the U.S. is now at 5,366 MWt with an annual utilization of 20,302 TJ. The largest increase in geothermal direct-use was in the heating of aquaculture pond and raceways. Ten new fish pond heating projects were recently identified in the Imperial Valley of California along with the expansion of two existing projects (Rafferty, 1999). Approximately 3.65 million kg of Tilapia, catfish and hybrid striped bass are raised annually. A second area identified as having a significant increase in aquaculture projects is along the Snake River Plain of southern Idaho. Seven new projects were identified in this area, adding an additional one million $\mathrm{kg}$ of Tilapia and catfish in annual production. These installations use cascaded water from artesian wells in raceways for raising their fish. Two district heating projects were expanded: the City of Klamath Falls and Oregon Institute of Technology. Both have also added snow melting. A total of $8,250 \mathrm{~m}^{2}$ of sidewalk and highway pavement snow melting have been added to these systems. Six greenhouse projects have also been expanded, two in California, three in Idaho and one in New Mexico for a total of 46.5 ha. Geothermal heat pumps have steadily increased over the past five years with an estimated 45,000 units installed annually of $12 \mathrm{~kW}$ size capacity. Of these, $46 \%$ are vertical closed loop, $38 \%$ horizontal closed loop and $15 \%$ open loop systems. Projections for the future are that the installation rate will increase about $10 \%$ annually, so that by 2010 an estimated 120,000 new units would be installed in that year. It is estimated that 400,000 units are presently installed in the U.S., thus, this rate would add an additional 1.1 million units for a total of about 1.5 million units by 2010 . The majority of the installations are in the mid-west and southern states (from North 
Dakota to Florida). Data from individual space heating and pool heating were updated with missing information added. Thi $\mathrm{S}$

increase, in most cases, is not due to new installations, but reflects the gathering of better data.

\section{South America}

Argentina: This southern country leads South America in geothermal utilization. The emphasis on geothermal development has been in the area of direct-utilization, as the small geothermal binary power plant $(670 \mathrm{~kW})$ at Copahue went off line in 1996 (Pesce, 2000). A National Geothermal Plan has been instituted to raise interest in geothermal development. New direct-use developments have taken place in northeastern Argentina where six new thermal areas have been exploited for recreational and therapeutic purposes, which has produced new economic activity in that region. In the western part of the county, on the flanks of the Andes at Copahue-Caviahue, projects using thermal fluids to heat streets and access roads for a ski resort area has been completed. This area is an international thermal center with capacity to supply 2,500 thermal baths a day. Until the installation of the snow melting system, the village was only open in summer from December to April, as winter storms could cumulate up to four meters of snow on the streets. South of Buenos Aires, greenhouse heating, shrimp farming and a thermal therapeutic center were developed. Further south, in Chubut Province, a project using thermal fluids for trout farming is under development. At present there are 134 direct use projects with an installed capacity of $25.71 \mathrm{MWt}$ and an annual energy use of $449.24 \mathrm{TJ}$.

Bolivia: The main effort in this country is a study of the geothermal Sol de Mañana of Laguna Colorado in southern Bolivia near the Chilean border (Terceros, 2000). Engineering services for field studies were contracted to the Federal Commission of Electricity (CFE) of Mexico. As a result, the field as been certified to generate at least 120 MWe over 25 years. The generated electricity will be distributed in the local market for mining, processing of minerals and use by the local populations. A 5 MWe pilot plant will be installed initially. No direct utilization is planned.

Columbia: After more than 30 years of trying to develop the geothermal potential of Colombia, there is no concerted effort to explore and assess the geothermal resources of the entire country (Alfaro, et al., 2000). Until recently, the availability of other sources of conventional energy prevented geothermal from being exploited. However, the 1992-93 energy crisis, alerted the authorities and the community about the necessity for exploring alternative energy sources. There are, however, current geothermal direct utilization in the form of approximately 38 bathing and swimming sites with an estimated installed capacity of 13.3 MWt and annual energy use of $266 \mathrm{TJ}$.

Others: There are many potential geothermal sites in Chile, $\mathbf{E}$ cuador and Peru along the front range of the Andes, but no papers were prepared from these countries for the Congress. Based on the authors' personal knowledge there is direct utilization of geothermal waters at spas in Chile and Peru, however, the size is unknown. In Peru there are at least two spas at Ariquipa, three in the Colca River Valley and two in th e Cotahuasi River Valley (Huttrer, 2000). Plans are also being made to develop the geothermal resources in southern Peru and at El Tatio in Chile. In southern Chile at Puyehue a resort hot el, Termas Puyehue, uses five different springs from 41 to $54^{\circ}$ $\mathrm{C}$ for bathing. Venezuela has several small spas and is invest igating a geothermal resource in the El Pilar area that has the potential for electricity generation but also for greenhouse hea ting, drying of agricultural and forestry products, spas and tou rism (Urbani, 1999). These spas are estimated to have a capa city of 3.5 MWt and use of $70 \mathrm{TJ} / \mathrm{yr}$.

\section{Asia}

China: Zhang et al., (2000) discusses geothermal developments within the country over the last 10 years. They report on studies that have identified more than 3,200 anomalies in China of which some 50 geothermal fields have been investigated and explored. An annual increase of $12 \%$ for the past 10 years is reported. Non-electrical use has developed rapidly, particularly in the last 5 years, especially in the areas of space heating, sanatorium use and tourism. By the end of 1998 low temperature use was $8,000,000 \mathrm{~m}^{2}$ of space heating, $700,000 \mathrm{~m}^{2}$ of greenhouses, $3,000,000 \mathrm{~m}^{2}$ of aquaculture ponds, and over 1600 sites of spa and sanatorium use of geothermal energy. The total capacity originally reported for non-electrical use was $4,310,000 \mathrm{t}$ standard coal (approx 118,569 TJ), however, this figure has been modified to $31,403 \mathrm{TJ} / \mathrm{yr}$ based on an $8 \%$ annual growth rate. The future of geothermal exploitation in China is discussed; R \& D and setting up of standards for materials and equipment are prominent in the plans. A paper by Cai, (2000) discusses the technical progress of space heating in Tianjin. The application of four types of space heating in use in Tianjin are presented. Axelsson et al., (1998) have studied the Tanggu (Tianjin) geothermal reservoir as there are indications that the field is over exploited. They recommend a comprehensive management program be put in place and in particular an improvement in the energy efficiency of space heating in the district should be attempted where a $50 \%$ reduction in hot water use should be possible. Huang, (2000) presents a historical review of developments in China and includes a discussion on the transport of geothermal fluids over long distances for direct use. Wang et al., (2000a) discusses utilization in Hebei province, where 80 hectares of aquaculture plant, $183,200 \mathrm{~m}^{2}$ of district heating, 13 medical treatment facilities and 63 bathing units are part of the 119 sites that have been developed in the past 20 years utilizing geothermal fluids. The same authors Wang et al. (2000b), discusses the geological and development strategy in Xiong County geothermal field. Zhu, (1999) presents an overview of developments of low temperature use $(<$ $150^{\circ} \mathrm{C}$ ) China with $2,410 \mathrm{MWt}$ installed and this is also reported by Liao (1997). Using this value, it was then extrapolated to 2000 at 2,814 MWt installed. The emphasis is on the replacement of coal fired projects with geothermal. It is projected to replace 13.4 million tonnes of coal by geothermal over the period $2001-2010$. Although no heat pumps are currently operating in China it is recorded in this paper that the absorption heat pump is being researched.

India: The seven major geothermal provinces of India enclose nearly 400 springs, Chandrasekharem, (2000). Exploration and pre-feasibility studies on promising geothermal provinces have demonstrated that commercial exploitation of these reserves has to be initiated. All of the current direct use recorded is used for 
bathing however the paper does discuss a project involving the use of geothermal fluids for drying onions in Andhra Pradesh province and a project for removing Cesium from the Puga waters is described. The Tattapani geothermal field is reported by Sarolkar and Pitale, (2000) to have possibilities of using the effluent from a $300 \mathrm{~kW}$ binary plant for further use in direct heat plant. 1800 liters $/$ minute of $100^{\circ} \mathrm{C}$ water is produced from 5 wells. A number of schemes for utilization of the effluent are discussed. The water, which is fairly benign, is finally used for irrigation.

Indonesia: The developments in Indonesia have been centered on producing electricity. About $3.4 \%$ of the total mixed elec-t rical energy can be attributed to geothermal by the year 2000, as reported by Sudarman et al. (2000). The only recorded direct use is for 5 sites where a total capacity of $7.3 \mathrm{MWt}$ with an annual energy use of $42.6 \mathrm{TJ}$ is used for bathing. The severe economic crises that started in late 1997 has adversely affected power sector demand and growth in Indonesia, Fauzi et al., (2000).

Israel: Some 430 deep oil and structural wells have been drilled in Israel, Greitzer and Levitte (2000). Most of these wells have been abandoned or are not in use. Thermal gradients and isotherm maps were estimated from the accumulated data. About 100 of these wells have been studied for possible geothermal use. A number of them were selected for spas and others, particularly in the Dead Sea Rift, are used for greenhouses. Thermal waters used for health and recreation utilize waters from both springs $\left(26-62^{\circ} \mathrm{C}\right)$ and deep drillholes $\left(42^{\circ} \mathrm{C}\right)$. Greenhouses use brackish water from the Mash'abbe Sade well field in the northern Negev. In the south, $80 \mathrm{~km}$ from the Dead Sea, $60^{\circ} \mathrm{C}$ water is available and in the Paran area 30 $-33^{\circ} \mathrm{C}$ is used for heating greenhouses. Fish farming in the north close to the Jordan Valley and south along the Mediterranean coast, $70 \mathrm{~km}$ north of Tel-Aviv, utilizes warm brackish water at $26^{\circ} \mathrm{C}$. In all $1787 \mathrm{~kg} / \mathrm{s}$ of fluid are used with a capacity of 63.3 MWt and an annual energy use of $1654 \mathrm{TJ}$.

Japan: Sekioka and Yoshii, (2000) presents detailed analysis of the use of geothermal fluids throughout Japan using a new version of a database developed by the New Energy Foundation. Installed thermal power is $253 \mathrm{MWt}$ with the maximum in Hokkaido Prefecture $(81.8 \mathrm{MWt})$. The major use is for space heating at $152 \mathrm{MWt}$. Annual energy use is $5772 \mathrm{TJ}$ with maximums in Hokakaido Prefecture and for space heating. $\mathrm{H}$ okakaido uses $2050 \mathrm{TJ}$ and space heating is attributed with 38 62 TJ. Space heating has a capacity factor of 0.81 with the highest factor being 0.92 for fish and animal heating. A small use of heat pumps is indicated which are concentrated in the cold and snowy Prefecture of Okayama. Hot spring water above $15^{\circ} \mathrm{C}$ is available all over the country so there is little demand for heat pumps.

Jordan: Investigations across the country in the last 30 years have revealed good prospects for low enthalpy use of geothermal fluids, Swarieh (2000). The geothermal gradient map of Jordan reveals two distinct regions of high geothermal gradients up to $50^{\circ} \mathrm{C} / \mathrm{km}$. These are in the vicinity of the east side of the Dead Sea and near the border with Syria and Iraq. In this region several thermal wells discharge water from the Upper Cretaceous Limestone. The thermal water from the springs and wells range in temperature from 30 to $63^{\circ} \mathrm{C}$. These springs and wells are currently used for spas and recreation. The estimate $\mathrm{d}$ capacity for bathing and swimming is $153.3 \mathrm{MWt}$ with an annual utilization of $1540 \mathrm{TJ}$. Giving an average capacity factor of 0.42 . The medicinal uses of the thermal waters of the springs has long been recognized and the paper discusses briefly the application of the fluids to greenhouse heating, fish farming and refrigeration by absorption.

Korea: Geothermal resources are primarily and traditionally centered on public bathing facilities (Yum, 2000). Current plans do not envisage utilizing geothermal for electric power generation. Over the period $1992-1998$ the Korean Institute of Geology, Mining, \& Materials (KIGAM) has conducted geological surveys for more than 200 outcrops and made temperature logs from 350 bores nationwide with depths from $150-1500$ metres. Fifteen of the older geothermal areas, which have 233 wells and 452 hot springs with temperatures ranging from 25 to $75^{\circ} \mathrm{C}$, were visited by more than 24 million users in 1994. There are about 100 newer areas with temperatures in the range 25 to $50^{\circ} \mathrm{C}$ where $42 \mathrm{spa}$ facilities have been constructed up to 1997 . Geothermal waters are also used in district heating and industrial use but no statistics are available.

Nepal: Geothermal manifestations occur in more than twenty eight localities in Nepal mainly scattered along the Main Central Thrust and the Main Boundary Fault, Ranjit (2000). The surface temperatures of thermal water varies between $23^{\circ} \mathrm{C}$ and $73^{\circ} \mathrm{C}$. The popularizing of the use of low temperature water through the media has drawn the energy planners. As a result the Ninth Plan of Nepal (1997-2002) has undertaken to prepare and/or update the inventory of geothermal localities and also to conduct a few pilot projects. Hot springs throughout the country used for tourist and religious purposes have long been popular but recent media coverage has increased their popularity. The Singha hot spring in western Nepal is one that people from distant places visit. Preliminary analysis of waters and isotopic studies indicate that there exists a large reservoir in western Nepal. Drilling activities for large-scale utilization of geothermal water has been limited by road access. The government is now placing emphasis on road construction which will open up areas for development. Currently all the logged data are for bathing at spas etc. A total capacity of 1.06 MWt is estimated with an annual energy use of $22.2 \mathrm{TJ}$

Philippines: Karunungan and Requejo (2000) presents the update for geothermal development in the Philippines and mainly discusses the power industry. However, they make the point that the Asian crisis although not cutting off expansion, has curtailed plans and restricted growth of the industry. Two papers, Chua et al. (1996) and Adajar (1999), discuss the details of pilot plants for multi crop drying plant, one attached to the Southern Negros power project of PNOC and the other a $\mathrm{t}$ Manito in the province of Albay about $20 \mathrm{~km}$ north east of the Bacon-Manito power project. The Southern Negros pilot 1 MWt plant, which was referred to in Freeston $(1995,1996)$ is described in detail by Chua et al. (1996). At that time it was anticipated that other plants of similar design would be in use in other areas and would seem to be moving in that direction.

Thailand: The paper by Ramingwong et al. (2000) details the studies that have been ongoing since the 1995 report, however 


\section{Lund and Freeston}

it appears that little progress has been made in developing ope rational projects. The $0.3 \mathrm{MWe}$ Ormat plant at Fang has co ntinued to operate at high load factors and the air conditionin g, cold storage and crop dryer using the $80^{\circ} \mathrm{C}$ exhaust from th e power plant has continued. Recently a new larger crop drye $r$ has been constructed and the Mae Fang National Park has $b$ uilt a public bathing pond and sauna room to serve visitors. $T$ he San Kampaeng, Pai and nine other geothermal systems are reported to be under further investigation but to date no other above ground developments have taken place. Charusiri et al. (2000) discusses hot spring and heat flow data collected in S E Asia and their application to Tectonic settings.

Turkey: Turkey has been in the forefront of direct use application and development in recent years. Freeston (1995, 1996) reported an installed capacity of $140 \mathrm{MWt}$, Batik et al. (2000) at this conference, has a figure of $820 \mathrm{MWt}$ installed with an annual energy use of 15,756 TJ. Most of the development has occurred in space heating where 51,600 residences have geothermal heating (493 MWt) with 45.4 ha of geothermal greenhouse heating and 194 spas used for balne o-logical purposes $(327 \mathrm{MWt})$. Engineering design to supply a further 150,000 houses with geothermal heat is complete. The projections for 2010 is 3,500 MWt (500,000 residences equivalent which is about $30 \%$ of the total residences in the country), of heating and $895 \mathrm{MWt}$ for spas and by 2020,8300 MWt (1.25million residences equivalent) of heating and 2300 MWt of spas will be complete. Construction costs for heating are $850-1250 \mathrm{US} \$ / \mathrm{kW}$ and the cost per residence around 2000 US\$ for investments that are paid back in 5-10 years. At Kizi ldere geothermal field where $12-15 \mathrm{MWe}$ is produced, a liqui $\mathrm{d} \mathrm{CO}_{2}$ and dry ice production factory utilizes geothermal fluid to produce 120,000 tonnes annually. Kocak (2000) dis-cusse $\mathrm{s}$ the setting of the geothermal fields in Turkey and gives detai ls of both the high and low enthalpy geothermal areas.

Other countries: Iran has continued exploration activities since that reported in 1995, Fotouhi and Noorollahi (2000). Sarein area in the Sablan region where there are hot springs, is targeted for direct use utilization. Bakht (2000) provides a good overview of the geology and related geothermal resources of Pakistan, however there is no use of fluids reported.

\section{Europe}

Europe has only geothermal electric power generation in Iceland (170 MWe), Italy (785 MWe) and Portugal (Azores) (16 MWe), however, most countries have some form of direct utilization, mainly in the form of heating swimming pools and spas, or using geothermal heat pumps for space heating.

Albania: Studies have been carried out oriented toward the distribution of geothermal fields and the natural thermal water springs and wells (Frasheri, 2000). This includes temperature measurements, and the calculation of geothermal gradient and heat flow density. Approximately 145 wells have been logged along with the chemical analysis of eight springs. Artesian wells have fluid temperatures as high as $65.5^{\circ} \mathrm{C}$ and the springs reach $60^{\circ} \mathrm{C}$. Two direction of exploiting these resources are pro-po sed: first to use the thermal water springs and wells of low enthalpy, and secondly, the use of deep doublet in abandoned oil and gas wells and single well using a "Vertical Earth Heat Probe." No direct-use is listed for Albania.

Austria: The period since 1995 has seen a lot of activities on exploitation of geothermal energy in Austria (Goldbrunner, 1999). In this time 17 wells have been drilled for a total of $31,875 \mathrm{~m}$. Three of these were injection wells which were drilled in the Upper Austrian Molasse Basin. At present Austria has four geothermal plants (all in Upper Austria) which inject the water. At one site (Geinberg) cascaded geothermal use is now performed which includes district heating, spa heating, use of thermal water for bathing, swimming and balneology and greenhouse heating. The temperature use at 12 sites vary from 33 to $95^{\circ} \mathrm{C}$. The drilling of deviated injection wells were supported by the European Union via the Thermie A program. The installed capacity of the direct-use projects is $27.3 \mathrm{MWt}$ and the annual utilization is $515.1 \mathrm{TJ}$. There is also an estimated 19,000 geothermal heat pump installation in the country with an annual increase of 1,600 (Rybach and Sanner, 1999). Based on typical values of $12 \mathrm{~kW}$ per installation, COP of 3.0 and 2,000 equivalent full time operating hours in the heating mode, would give $228 \mathrm{MW}$ installed capacity and $1094 \mathrm{TJ} / \mathrm{yr}$ utilization.

Belgium: There has been no new geothermal development in the country since the 1995 country update (Vandenberghe, 1999). Production is mainly concentrated in the Mons area, in southwest Belgium ( Berckmans and Vandenberghe, 1998). The $g$ ov-ernment is aware that in the future the geothermal issue wi 11 be raised again if energy prices start to rise. The Flemish go vern-ment has a technology research facility (VITO), which e $\mathrm{m}$-phasizes the use of $<25^{\circ} \mathrm{C}$ aquifers for cold/heat storage pur -poses for large buildings. In addition a study is commissioned to evaluate what the governments position should be regardin g HDR (Vandenberghe, 2000). In north Belgium, swimming p ools are heated at Herentals and Turnhout. There is also a fis $\mathrm{h}$ farm at Turnhout. In south Belgium water is used to heat $\mathrm{sc}$ hools, swimming pools, sport facilities and residential buildings. The water is then cooled from $50^{\circ}$ to $40^{\circ} \mathrm{C}$ to heat a greenhous e of $4,000 \mathrm{~m}^{2}$, and further cooled to $30^{\circ} \mathrm{C}$ to heat waste muds at Wasmuel. The well water at Bouvrain is used to heat a local hospital (Berckmans and Vandenberghe, 1998). The total installed capacity is $3.89 \mathrm{MWt}$ and the annual energy use is 107.1 TJ.

Bulgaria: Geothermal research and development has progressed at a slow pace in the last five years (Bojadgieva, et al., 2000). The government has withdrawn their support and the private industry has been generally involved only in bottling of potable water and soft drinks. Only two small demonstration projects for space heating and hot tap water, entirely financed by PHARE program have been completed at two geothermal cities. A small geothermal installation for school heating was partially funded by the state. The major applications of thermal water in the country is in balneology, for space heating and air conditi on-ing, for domestic hot water, for greenhouses and aquaculture, swimming pools and bottling. There is some processing of flax and hemp fibers, and a small enterprise for the extraction of iodine, bromine, boron, strontium, etc., from the thermal water is in operation near Varna on the northern Black Sea coast. The total installed capacity is now $107.2 \mathrm{MWt}$ of which 13.3 is due to geothermal heat pumps. Compared to 1995 about $2.5 \mathrm{MWt}$ of direct utilization was removed due to maintenance problems 
and $0.85 \mathrm{MWt}$ were added. The annual utilization is $1637.2 \mathrm{TJ}$ of which 162.0 is due to geothermal heat pumps. The direct utilization is distributed between eight sites in the country.

Croatia: Low temperature thermal water is widely used for ba th-ing, swimming and medical purposes in traditional spas, so me of which are also equipped with geothermal space heating sys-tems (Jelic et al., 2000). Only two out of ten geothermal $\mathrm{f}$ ields discovered during the hydrocarbon exploration activities are currently in use. According to the Program of Geothermal Energy Utilization GEOEN, in the near future the energy from the majority of the geothermal fields should be directly used for space heating and in the agricultural sector for greenhouse hea t-ing and industrial processing of fruits and vegetables. Beside the direct heat applications, the construction of a geothermal electric power plant is planned for 2005. There are 18 sites in the country using geothermal energy with an installed capacity of 113.9 MWt and annual energy use of $544.8 \mathrm{TJ}$.

Czech Republic: The geothermal resources are available either directly in the tectonic structures of the crystalline Bohemian Massif or in sedimentary basins covering the Massif which represent secondary accumulations of geothermal heat (Stibitz, 1999). Geothermal heat of low-enthalpy is used for domestic and swimming pool water heating, and for some small industry. The most famous spa use are at Karlovy Vary (Karlsbad) and Mariánské Lázně(Marienbad) along with five others (28 to 7 $2^{\circ} \mathrm{C}$ water) in the western part of the country with an estimated 4.5 MWt capacity and $90 \mathrm{TJ} / \mathrm{yr}$ (Lund, 1990). About 390 ge o-thermal heat pumps have been installed with a total of 7.95 MWt capacity and an estimated $38.2 \mathrm{TJ} /$ year (350 vertical and 10 horizontal ground coupled, and 30 water source installa-tio $\mathrm{ns})$. The small scale private installations are typically used for heating of family houses (output less than $20 \mathrm{~kW}$ ), hotels, accommodation facilities, swimming pools and small businesses (20 to $100 \mathrm{~kW}$ ) as well as three water treatment plants using heat pumps with output more than $100 \mathrm{~kW}$ each. A heat pump with $1 \mathrm{MW}$ output has been installed at the Prokop Mine of th e Pribram ore mining district. The warm water is pumped from the mine shaft at $28^{\circ} \mathrm{C}$, run through the heat pump where the water is then used for heating the mine facilities as well as the adjacent administrative buildings. Future project possibilities included a $15 \mathrm{MW}$ heat pump in the town of Breclav for district heating, direct-use in a soap factory and swimming pool in Tr ekov, two projects in Mušov and Pisek for thermal spas, swimming pool and greenhouses heating, and a power plant in the region close to the Czech-German border (Doupovske vrchy and Bozi Dar).

Denmark: The country has widespread geothermal aquifers, which can be used for district heating (Mahler, 2000). How-e ver, combined heat and power (CHP) plants cover the heat demand on the Danish district heating networks. The Danish geothermal development has thus been concentrated on a single geothermal plant in Thisted (northern Jutland). This plant uses an absorption heat pump driven by an incineration CHP plant. The plant was recently expanded and now uses $150 \mathrm{~m}^{3} / \mathrm{hr}$ of a $15 \%$ saline $45^{\circ} \mathrm{C}$ geothermal water. The capacity of the system is $4 \mathrm{MWt}$ and produces $53.9 \mathrm{TJ}$ of annual heat energy. Appro xi-mately 250 ground water based heat pump units were instal led in the early eighties and an additional 37,500 ground and air- based heat pumps are also installed; however, it is unknown how many of these are ground coupled. The 250 groundwater units have an approximate capacity of $3.0 \mathrm{MWt}$ and annual energy use of $20.8 \mathrm{TJ}$.

Finland: The most promising forms of geothermal energy in Finland are restricted to the utilization of ground heat with heat pumps (Kukkonen, 2000). This is due to the geological condi -tions as Finland is a part of the Fennoscandian (or Baltic) Shield. The bedrock is Precambrian covered with a thin $(<5 \mathrm{~m})$ cover of Quaternary sediments. Topography is subdued and does not easily produce advective re-distribution of geothermal heat by groundwater circulation systems. Due to the crystalline character of the bedrock, rock porosity and its water content are low. This practically excludes geothermal systems utilizing hot wet rock. Nevertheless, promising applications can be found for small-scale use of ground-stored heat in all parts of the country. About 10,000 heat pumps have been installed in boreholes, lakes or Quaternary deposits since the early 1980's. About 70\% are horizontal and $10 \%$ vertical ground coupled systems and $20 \%$ use lake water. Typical vertical installations are in small family houses using a shallow 100-200 m deep borehole, extracting about $50 \mathrm{~W} / \mathrm{m}$. The total installed capacity is 80.5 MWt and the annual energy use is $484 \mathrm{TJ} / \mathrm{yr}$ (based on 4000 full load hours per year and average capacity of $8 \mathrm{~kW}$ ). The use of ground heat with geothermal heat pumps is currently increasing in Finland.

France: The development of geothermal energy began as the result of the two energy crises in the 1970s, with an important development of activity from 1978 to 1987 , when energy prices fell. During this nine-year period more than 70 geothermal district heating operations were constructed providing heat and hot water for around 200,000 housing units. During the early 1990s, with cheap energy, financial support for renewable energy was reduced. In 1997, with the Greens being elected to the French Parliament and with the necessity of controlling $\mathrm{CO}_{2}$ emissions, the French authorities expressed renewed interest in renewable energies and energy management, and thus, in 1998 increased their financial support for these activities. The fol-1 owing priorities were planned for geothermal energy: (1) continuation of the HDR program, (2) dissemination of ground-s ource heat pump technologies, (3) development in the use of high-enthalpy resources in the French Overseas Departments, and (4) development in the use of metropolitan low-enthalpy resources with an extension of the existing geothermal district heating plants to new consumers, and an extension of the during of the Long Term Guarantee System by 10 years. Out of the 74 plants operating at the end of 1986, only 61 are still in operation today: 41 in the Paris region, 15 in the Aquitaine Basin, and five in other regions (LaPlaige, et al., 2000). They heat and pr o-duce hot water for around 200,000 housing units. About one third of the plants in the Paris Region are profitable, one third break even and one third show a deficit. The installed capacity in the Paris Basin is $295 \mathrm{MWt}$ with an annual energy use of $4,434 \mathrm{TJ}$, and elsewhere in the country such as at Bordeaux and including two greenhouse locations ( $8 \mathrm{MWt}$ and $124 \mathrm{TJ} / \mathrm{yr}$ ), the installed capacity is $31 \mathrm{MWt}$ and the annual energy use $461 \mathrm{TJ}$. Assumed within the district heat system are an estimated 2,750 heat pump units installed from 1993-1996 (Rybach and Sanner, 1999). Extrapolating this to 1999 gives 4,000 units with a n 
installed capacity of $48 \mathrm{MWt}$ and utilization of $255 \mathrm{TJ} / \mathrm{yr}$. This gives a total for the country of $326 \mathrm{MWt}$ and $4895 \mathrm{TJ} / \mathrm{yr}$ (Des plan, 2000).

Germany: By the end of 1999 direct thermal use of geothermal energy in Germany amounted to an installed thermal power of approximately $397 \mathrm{MWt}$ (Schellschmidt, et al., 2000). Of this sum, approximately 53.2 MWt are generated in 27 major centralized installations. Small, decentralized earth-coupled heat pumps and groundwater heat pumps are estimated to contribute an additional $344 \mathrm{MWt}$ from at least 18,000 installations. By the year 2002 an increase in total installed power of about $120 \mathrm{MWt}$ is expected: $82 \mathrm{MWt}$ from major central and $40 \mathrm{MWt}$ from small, decentralized installations. This would boost direct thermal use in Germany close to an installed thermal power of $517 \mathrm{MWt}$. At present no electric power is produced from geothermal resources. The large centralized installations comprise heating plants, thermal spas sometimes combined with space heating, and in some cases, greenhouses and clusters of ground heat exchangers used for space heating and cooling. Most are located in the north German sedimentary basin, the Molasse Basin in southern Germany, or along the Rhine Graben. Direct- use of geothermal heat for space heating in small decentralized units is widespread in Germany. Depending on the local conditions these units consist of earth coupled heat pumps (horizontal heat collectors, vertical heat exchangers), or groundwater heat pumps. The estimated annual energy use is $419 \mathrm{TJ}$ from direct use and 1149 $\mathrm{TJ}$ from individual heat pumps.

Greece: During the period 1995-99, geothermal research and applications were mainly related to low enthalpy fields (Fytikas, et al., 2000). The areas of research included northern Greece (Thrace, Macedonia), NW Greece (Epirus), Chios and Lesvos islands (Aegean Sea). In Thrace, near the village Arisino, a new geothermal field was discovered with temperature approaching $92^{\circ} \mathrm{C}$. In NW Greece, exploration wells discovered temperatures of $48^{\circ} \mathrm{C}$, and on Chios a recently discovered field produced $90^{\circ} \mathrm{C}$ water. Many new developments have occurred in the last five years, including heating of greenhouses, subsurface soil heating for early asparagus cultivation, production of spirulina, heatin $\mathrm{g}$ a hotel in the neighborhood of Nea Appollonia hot springs (Macedonia), and a spa complex in Thrace and applications that use heat pumps near Athens and on the island of Rhodes. Heat pumps have been installed for both heating and cooling. The first one was in a private house near Athens $(35 \mathrm{~kW})$ and the second in the Municipal building in Rhodes $(140 \mathrm{~kW})$. In addition, a heat pump coupled with ground heat storage is used for heating and cooling a $6000 \mathrm{~m}^{2}$ office building using $36^{\circ} \mathrm{C}$ water with a rating of $220 \mathrm{~kW}$. The geothermal power plant on Milos has remained shut down since 1989. The direct-use installed capacity is $56.7 \mathrm{MWt}$ and annual energy use is 382.3 TJ. In addition, for heat pumps the installed capacity at five sites is $0.40 \mathrm{MWt}$ and the annual use is $3.1 \mathrm{TJ}$.

Hungary: During the years since WGC'95 there have been six new geothermal developments in Hungary (Arpasi, et al., 2000). Geothermal is used directly by 94 different organization at 42 locations. The majority of the geothermal capacity and annual use is in greenhouse heating at 48 different locations (63.7\%), followed by space heating $(22.5 \%)$. There are two industrial users and four spas. Three pilot projects are under study by the
Hungarian Oil and Gas Company (MOL) to develop geothermal electric power plants and then cascaded direct use projects (mainly for the heating of greenhouses). The installed capaci ty is $324.6 \mathrm{MWt}$, suppling 2804.3 TJ annually. This does not include use for swimming and bathing at spas which adds another 14.2 MWt and $358 \mathrm{TJ} / \mathrm{yr}$. Geothermal heat pumps represent an additional $3.8 \mathrm{MWt}$ of installed capacity, which is estimated to provide $20.2 \mathrm{TJ} / \mathrm{yr}$. This gives a total of 342.6 MWt and 3,182.5 TJ/yr.

Iceland: Geothermal energy plays an important role in the energy supply of the country. It provides about $50 \%$ of the total primary energy supply (Ragnarsson, 2000). The principle use of geothermal energy is for space heating where about $86 \%$ of all houses are heated with geothermal water. The benefits of geothermal heating are of great importance since heating is required almost all year and it saves about 100 million US\$ in imported oil. A total of 26 municipally owned geothermal district heating system are located in Iceland, the largest of which is in Reykjavik serving 160,000 people. On the $1^{\text {st }}$ of January, 1999, a new company was established by the merger of Reykjavik District Heating and Reykjavik Electricity: Reykjavik Energy (Orkuveita Reykjavikur), which is responsible for the distribution and sale of both hot water and electricity in the city. In December, 1998, a new geothermal district heating system started operation in northern Iceland at Arskogsstrond (population 270). Another new geothermal district heating system for the village of Stykkisholmur in the western part of Iceland is now under construction (population 1,300) and expected to be fully operational in the fall of 2000 . There are about 100 public swimming pools and about 30 pools in schools and other institutions heated by geothermal energy with a combined surface area of $27,000 \mathrm{~m}^{2}$ - most of which are openair and in constant use throughout the year. The use of geothermal energy for snow melting has been wide-spread for the past 15-20 years. This kind of utilization gained popularity when plastic pipes for hot water were introduced in the market. Spent water from houses, at about $35^{\circ} \mathrm{C}$, is commonly used for deicing of sidewalks and parking spaces. The total area now covered by snow melting systems is estimated to be $350,000 \mathrm{~m}^{2}$, of which about $250,000 \mathrm{~m}^{2}$ are in Reykjavik. The main industrial uses of geothermal steam are for the diatomite drying plant at Mývatn in northern Iceland where about 27,000 tonnes per year are produced. At Reyhólar, a seaweed processing plant uses geothermal energy for drying with an annual production of 2,000 to 4,000 tonnes. The pilot salt plant on the Reykjanes Peninsular was closed down in 1994; however, a small part of the plant was restarted in 1999 and full operation is now under preparation. The most recent industrial application is drying of hardwoods from North American. A plant for the commercial production of liquid carbon dioxide has been in operation at Haedarendi in southern Iceland since 1986. At the end of 1997 the production of $\mathrm{CO}_{2}$ was increased from $40 \mathrm{~kg}$ per hour to 250 $\mathrm{kg}$ per hour, which is sufficient to meet current industrial demand in Iceland. Some $183,000 \mathrm{~m}^{2}$ of greenhouses and $105,000 \mathrm{~m}^{2}$ of soil heating are primarily located in southern Iceland. The greenhouse production is divided between different types of vegetables (55\%) and flowers (45\%). Most of the greenhouses are constructed of glass, as plastic film does not stand up well in the windy climate. At present there are about 50 fish farms in operation, with many of them using geothermal hot water to heat freshwater from 5 to $12^{\circ} \mathrm{C}$ mainly for raising 
salmon (70\%), but arctic char and trout are also raised. The total fish production is about 4,000 tonnes per year. Today $t$ he installed capacity is 1,469 MWt and 20,170 TJ annual energy use. This includes $4 \mathrm{MWt}$ and $20 \mathrm{TJ} / \mathrm{yr}$ for a few heat pump installations, mainly of large capacity.

Italy: The lack of economic incentives for direct use of geothermal heat prevented the research and development of lo w-temperature resources and made it difficult to develop new projects using fluids already available (Cappetti, et al., 2000) In Italy, the vast majority of geothermal development is based on steam-dominated reservoirs, so waste steam with high enough temperatures are generally not available. Under these circumstances, heat has to be supplied by means of geothermal steam subtracted from the electricity generation; the subsequent loss of generation has to be charged to the heat user, resulting in increased costs, especially when the electricity produced with that steam benefits from the state subsidies. Despite this, some progress has been made over the last five-year period. The district heating of many villages in the Larderello area (Monte cerboli, Serrazzano, Lustignano, San Dalmazio and Sasso Pis ano) accounts for the largest amount among the new applications, even though the unit capacities are small. These plants are fed by steam supplied by ERGA (the new energy company owned by ENEL) and operated by local municipalities. In Larderello, the local swimming pool has re-opened after many years of closure and features a brand-new geothermal heating system. New greenhouses have been built in the Radi condoli area, and finally an industrial plant for the transformation of dairy by-products has been built in Carboli, in the southernmost part of the Larderello field. Existing greenhouse in Castelnuovo V.C. have been dismantled; and most importantly, the Vicenze district heating system has been converted from geothermal to natural gas. The recent start-ups of geothermal power plants in the water-dominated fields of B agnore and Latera will make available large quantities of waste heat in the sites for district heating and greenhouses. Elsewhere, direct-use of geothermal energy are mainly connected to the spa business, but a large share is also related with greenhouses and fish farming (Carella and Sommaruga, 2000). Geothermal space heating include hotel facilities in the Abano area and district heating at Ferrara, the use of heat pumps at Acqui Terme in NW Italy, and a district heating system in Bagno di Romana in the NE Appennines. Carella and Sommaruga (2000) estimate that there are 52 ha of greenhouses and four major fish farms in Italy using geothermal waters. Only about 100 individual heat pumps are estimated to be used. The installed capacity for direct-use is 324.6 MWt and the annual energy use 3767.4 TJ (Cappetti, et al., 2000), with space heating accounting for $41 \%$, bathing and swimming for $28 \%$, greenhouse heating for $22 \%$, indu strial process heat for $9 \%$, and fish farming for less than $1 \%$ o $\mathrm{f}$ the annual energy use. The 100 individual heat pumps are e stimated to account for $1.2 \mathrm{MWt}$ and $6.4 \mathrm{TJ} / \mathrm{yr}$.

Lithuania: The country has no volcanic activities and no hot springs, but has many reservoirs with warm geothermal water which can be used for district heating, and in health resorts and swimming pool (Suveizdis, et al., 2000). The geothermal potential in Lithuania was investigated through seismic exploration, investigation of oil and gas wells, and the drilling of geothermal exploration wells. Two wells were drilled in 1989 and 1993 with flow rates up to $50 \mathrm{~m}^{3} / \mathrm{h}$ and at a tempera ture of $72^{\circ} \mathrm{C}$. A geothermal demonstration district heating plant is being constructed at Klaipeda in cooperation with a Danish firm (Mahler, 2000). Two production and two injection wells have already been drilled. The plant will produce $49.7 \mathrm{MWt}$ (20.9 MWt from geothermal) from 500 to $700 \mathrm{~m}^{3} / \mathrm{h}$ of $38^{\circ} \mathrm{C}$ water and should be completed by the end of 1999. A second district heating plant is being proposed by a German firm which will extract $6.1 \mathrm{MWt}$ from up to $150 \mathrm{~m}^{3} / \mathrm{h}$ of $49^{\circ} \mathrm{C}$ water. Geothermal heat pumps are also being used in several locations. The installed capacity is $21.0 \mathrm{MWt}$ and the annual energy use is $598.8 \mathrm{TJ}$.

Macedonia: The country has over a 30-year tradition in geothermal energy utilization (Dimitrov et al., 2000). Today, about 15 geothermal projects are in operation or under development. Four of these are of major importance and have a general influence on the development of direct application of geothermal energy in the country. The most important are the Kocani project, the agricultural project at Gevgelija and Vinica, and the intergrated project at Bansko. The Kocani project consists of 18 ha of glasshouses, a rice-drying plant, and due to a successful new borehole, use of the energy is made in the paper industry, a factory for vehicle parts production, and the heating of dwellings. At Gevgelija 22.5 ha of glass houses are heated at one location, and a balneological project supplying a hotel complex with sanitary and spa water from a second location. The project at Vinica of supplying heat to 6 ha of glasshouses is not finished due to problems with corrosion of the pipes. At Bansko, a 2.2 ha greenhouse is heated, and the building, sanitary water and pool at the Car Samoil Hotel are heated with spring water. Future use include the continued injection of used thermal water, modernization and rehabilitation of old fashioned greenhouses and increasing the number of dwellings heated by geothermal energy. The installed capacity is $107.4 \mathrm{MWt}$ and the annual energy use is 509.6 TJ.

Netherlands: No new report was presented; however, a geothermal heat pumps program was initiated in 1995, which was intended to achieve a saving of conventional energy of 5-10 $\mathrm{PJ}$ in 2000 and $50 \mathrm{PJ}$ in 2010 (Walter, 1995). In 1997 it was estimated that 900 heat pumps were installed (Rybach and Sa nner, 1999). This estimate gives an installed capacity of 10.8 MWt and an annual energy use of 57.4 TJ.

Norway: No country update report was available from Norway; however, an estimate of the number of geothermal heat pump installations from 1993 to 1996 is made in Rybach and Sanner (1999). They estimate 4,000 total units of all kinds installed of which $8 \%$ or 320 are ground-source units. Extrapolating to th e end of 1999, this gives an estimated 500 units with $6.0 \mathrm{MWt}$ capacity and $31.9 \mathrm{TJ} / \mathrm{yr}$.

Poland: The country is characterized by large low-enthalpy resources connected with three extensive sedimentary geothermal provinces covering about $80 \%$ of the country (Ke pinska, et al., 2000). Geothermal energy use has been concentrated in space heating and balneology/bathing, while other uses such as greenhouse heating, fish farming, and timber drying are on an experimental scale. In 1999 two heating plants went on line in the Podhale Region and Pyrzyce town. A third plant in Mszczonow town went on line in 1999. At Podhale the 
plant serves 220 houses and the water is then cascaded for timber drying, greenhouse heating, fish farming, plant growing in heated soil and for space and domestic hot water heating at the PAS MEERI Geothermal Laboratory. By 2001-2002 geothermal heat will be delivered to about 4,400 customers in Zakopane. The Pyrzyce plant, opened in 1996, serves 12,000 customers. This system replaces a 20,000-tonne/yr coal fired plant. Geothermal is also planned to be used from recreation and agriculture. The Mszczonow plant is the most advanced of all the geothermal plants, supplying heat and drinking water for about 6,000 people. In 1999 , eight spas used $20-60^{\circ} \mathrm{C}$ waters from springs or wells for balneology and bathing. In addition, $\mathrm{CO}_{2}$, iodine-bromine for medical purposes and cosmetic salts are also extracted from geothermal waters. During the last several years, there has been increased interest in geothermal heat pumps. Two large sized units $(20.4 \mathrm{MWt})$ are used in th e Pyrzyce plant and a small unit uses ventilation air from a underground coal mine in Upper Silesia. In 1999 over 4000 ground-source and groundwater heat pumps were on line. The installed capacity is $68.5 \mathrm{MWt}$ of which $26.2 \mathrm{MWt}$ is from heat pumps, and the annual energy use is $274.7 \mathrm{TJ}$ of which $108.3 \mathrm{TJ}$ is from heat pumps.

Portugal: On the mainland in the northern part of the country, Chaves and S. Pedro do Sul springs have the highest temperature of $76^{\circ}$ and $69^{\circ} \mathrm{C}$ respectively (Aires-Barros and Marques, 2000). They are used for space heating, greenhouse heat, bathing and swimming. The municipal swimming pool at Chaves has been in operation since 1982 and uses water fro $\mathrm{m}$ a $150-\mathrm{m}$ deep well. The water is also used for space heatin $\mathrm{g}$ and domestic hot water. At S. Pedro do Sul the spring wate $\mathrm{r}$ is used at the local spas for bathing and swimming, with 20, 000 visitors in 1998, for heating a 2 ha greenhouse, and for he ating local hotels. Near Lisbon, a 1,500-m deep well with water temperature of $53^{\circ} \mathrm{C}$ is used to heat the Air Force Hospital since 1992. At São Miguel Island in the Azores, six small greenhouses covering about $200 \mathrm{~m}^{2}$ have been constructed. Experimental crops such as cape gooseberry, melon and pineapples are grown here. The greenhouses use waste water from a nearby geothermal power plant. The installed capacity is $5.47 \mathrm{MWt}$ and the estimated annual energy use is $35.1 \mathrm{TJ}$.

Romania: There are over 200 wells drilled with depths between 800 and $3,500 \mathrm{~m}$, that encountered geothermal resources at temperatures from 40 to $120^{\circ} \mathrm{C}$ (Cohut and Bendea, 2000). These wells have a total thermal capacity of about $480 \mathrm{MWt}$, of which 96 wells are used (of which 35 wells are used for balneology and bathing), producing water with temperatures from 45 to $115^{\circ} \mathrm{C}$. The main geothermal resources are in the northwest around Oradea (including Bors and the Western Plains) accounting for the majority of the use, in the Olt Valley in central Romania and just north of Bucharest. The main direct uses of geothermal energy are: space and district heating 35\%, bathing $30 \%$, greenhouse heating $23 \%$, industrial process heat $7 \%$, and fish farming and animal husbandry $2 \%$. During the past five years 14 wells were drilled. Due to the problems with the local economy, only three new geothermal projects were completed, one for direct use and two for bathing and swimming. Today there are 38 "geothermal localities" using the 96 wells. The total capacity is $152.4 \mathrm{MWt}$ with an annual energy use of $2870.7 \mathrm{TJ}$.
Serbia: There are four geothermal provinces in the country with more than eighty low enthalpy systems, the most important of which is located at the south edge of the Pannonian Basin in the north (Milivojevic and Martinovic, 2000). Geothermal energ $\mathrm{y}$ is being utilized for balneological purposes, in agriculture and for space heating with heat exchangers and heat pumps. There are 59 thermal water spas used for balneology, sports and recreations and as tourist centers. Certain archeological evidence indicates similar uses by the ancient Romans in some of the same localities. These waters are also bottled by nine mineral water bottling companies. In the Pannonian Basin, thermal water is used from 23 wells, two for greenhouse heating, three for heating pig farms, two for industrial process in leather and textile factories, three for space heating, and 13 for spas and for sport and recreation facilities. Outside of the Basin geothermal energy is used to heat greenhouses, a poultry farm , a textile workshop, in the carpet industry, for drying wheat and other cereals, and for spas and a hotels. The installed capacity is $80.0 \mathrm{MWt}$ of which $6.0 \mathrm{MWt}$ is for heat pumps, and the annual energy use is $2375 \mathrm{TJ}$ of which $40 \mathrm{TJ}$ is for heat pumps.

Slovak Republic: The distribution of geothermal aquifers occur in 26 prospective areas and structures with the potential for exploitation (Fendek and Franko, 2000). These aquifers lie at depths of 200 to $5000 \mathrm{~m}$ and the waters have temperatures between 20 and $240^{\circ} \mathrm{C}$ with a potential of 5,538 MWt. Prospecting and exploration have been carried out in 14 of these areas. Geothermal water is used in 13 agricultural farms (greenhouse heating and soil heating), in four localities for heating of service buildings, in one locality for sport hall heating, in two localities for fish farming, in one locality for restaurant heating and on 30 localities for recreational purposes (bathing and swimming). The total areas covered by greenhouses is about 27.4 ha. The first geothermal heating plant with a capacity of 8 MWt was put on line in Galanta in 1996. This system provides heat and hot water to 1236 flats and a hospital. Another large use is at Podhajska where the first geothermal doublet was drilled in the country. The geothermal water is used to heat a hotel, administrative buildings, greenhouses and swimming pools. A third large energy use is at Besenova in the Liptov Basin where a hotel, greenhouses and swimming pools are heated. Future geothermal energy utilization projects and being undertaken in Kosice, Poprad, L iptov, Skorusina and Ziar basins. The total installed capacity is 132.3 MWt of which 1.4 MWt is for heat pumps, and the annual energy use is $2118.3 \mathrm{TJ}$ of which $12.1 \mathrm{TJ}$ is for heat pumps.

Slovenia: The main use of geothermal energy is for space heating and for bathing and swimming (including balneology), the latter began on a large scale over 40 years ago (Kralj and Rajver, 2000). Other uses include greenhouse heating, industrial applications and the use of heat pumps. Space heating including domestic hot water, the largest geothermal use, is mostly implemented at spas. At Murska Sobota 300 dwellings are heated through heat exchangers. The second high use in Slovenia is for bathing and swimming. There are 24 thermal spas and recreation centers where swimming pools with a surface area of about $29,600 \mathrm{~m}^{2}$ are heated directly or indirectl y 
through heat exchangers and heat pumps. Most are located o utside. The total area of greenhouses is 4.5 ha which are locat ed at Catez. Flowers are grown for the domestic market. The industrial applications include heat for the leather industry at Vrhnika, and for cooling at a cement works and heating a swi mming pool at Trbovlje. Geothermal heat pumps are used at $\mathrm{s}$ even thermal spas and/or recreation centers for swimming poo 1s and space heating. Most are groundwater units (around 56) and less than 10 are ground-coupled units. The installed cap acity is $42.0 \mathrm{MWt}$ which includes $2.6 \mathrm{MWt}$ for heat pumps, a nd the annual energy use is $704.6 \mathrm{TJ}$ of which 46.8 is for heat pumps.

Sweden: No country update report was received from Sweden. However, based on their WGC'95 report (Alm and Bjelm, 1995) the only energy use is from geothermal heat pumps in the Scania area of southwestern Sweden. At that time a large plant near the city of Lund had been operating since 1986. The installed capacity was $47 \mathrm{MWt}$ and the annual energy use $960.2 \mathrm{TJ}$. More recently (1998) an estimate of the number of individual heat pumps in operation is reported at about 55,000 with a thermal capacity of 330 MW (Rybach and Sanner, 1999). A particular success story can be told of Strömstad, a town of 6,000 about $200 \mathrm{~km}$ north of Gothenburg. The rocky subsoil is not suited for district heating, and thus 140 ground-source heat pumps with a total of 400 borehole heat exchangers have been installed for heating of houses and apartment for 3,000 people (Sanner and Hellström,1998). The improvement of air quality in winter was reported to be significant. The estimated annual use of the 55,000 units is then $3,168 \mathrm{TJ}$ (based on 4,000 full load hours per year and a $\mathrm{COP}=3.0$ ). This then gives a total of $377 \mathrm{MWt}$ and 4,128 TJ/yr.

Switzerland: Geothermal direct-use developed rapidly over the last five years (Rybach, et al., 2000). The increase is due mainly to geothermal heat pumps, with about 21,000 borehole heat exchanger/heat pump systems installed in the country, mainly for single family dwellings and smaller building complexes. In addition, novel solutions like combined heat extraction/storage, energy piles and tunnel water are used and are supported by government aid. Thus, the Swiss mix of geothermal use has two main components: 1) shallow resource utilization through horizontal coils and borehole heat exchangers, foundation piles and groundwater wells, and 2) use of deep resources - deep borehole heat exchangers, aquifer use by single and doublet systems, and tunnel water. Heat pumps are the key components in practically all these utilization schemes. There are 17 locations where spas use geothermal well water for balneology, space heating and heating nearby hospitals. A successful drilling to tap deep aquifers is at Riehen where heat is used in a district heating network which has also be extended to the neighboring community of Lörrach in Germany, thus providing the first example of a trans-boundary geothermal use. Warm tunnel water, frequently encountered during construction, is used at four sites for space heating and domestic warm-water productions. Future work, supported by the Swiss Government, include research and promotion of pilot and demonstration facilities including experimental and theoretical work with borehole heat exchangers and deep heat mining. The later projects aims at producing electricity and/or heat by the hot dry rock technology between 2005 and 2010. The installe d capacity is about $550 \mathrm{MWt}$ of which $500 \mathrm{MWt}$ is fro $\mathrm{m}$ geothermal heat pumps, and the annual energy production is about 2,400 TJ of which 1,980 is from heat pumps. Annual growth for heat pumps is estimated at $15 \%$.

United Kingdom: There is a large scale district heating projects in the UK at Southampton and a greenhouse project at Penry $\mathrm{n}$ (Batchelor, 1995). At Southampton a direct-use low enthalpy project provides district heating from the Sherwood Sandstone aquifer at $76^{\circ} \mathrm{C}$ from a depth of approximately $1,800 \mathrm{~m}$. The 1987 project provides heat to the new Western Esplanade district in the center of town including a shopping center, offices, hotel and central baths. Geothermal energy provides $87 \%$ of the heat requirements and covers daily fluctuations in demand by means of storage tanks. A coal fired boiler provides back-up. The single geothermal well produces 10 to $15 \mathrm{~L} / \mathrm{s}$ at sustained rates, and $20 \mathrm{~L} / \mathrm{s}$ peak. The spent water is discharged into a nearby estuary through a main storm water sewer. The annual savings are 1,500 to 2,000 TOE and corresponding payback in approximately 14 year. The estimated capacity is 2.18 MWt and the annual energy use 17.17 TJ. Using other sources of energy, a combined heat and power generator and absorption heat pumps have been added in recent years and the system extended to other customers (Smith, 2000). At Penryn a 5.5 ha greenhouse project by Gabbons Nursery uses $22^{\circ} \mathrm{C}$ water for the hydroponic cultivation of tomatoes. A well, 275 $\mathrm{m}$ deep produces $5 \mathrm{~kg} / \mathrm{s}$ water from Paleozoic rocks. The pro ject has run profitably for 13 years with an estimated installed capacity of $0.10 \mathrm{MWt}$ and annual use of $0.82 \mathrm{TJ}$.. Geothermal heat pumps are found in both Scotland and England (Curtis, 2000). Approximately 25 houses used ground-coupled systems with a capacity of $62.5 \mathrm{kWt}$ and annual use of $0.27 \mathrm{TJ}$ in Scotland. In England there are approximately 15 domestic installations totaling $120 \mathrm{kWt}$ and annual use of $0.52 \mathrm{TJ}$. There are also about nine commercial installations totaling $450 \mathrm{kWt}$ and annual use of $1.94 \mathrm{TJ}$. Closed loop systems are expected to grow in the UK. Direct use of open loop systems mainly for cooling is also expected to grow to counteract the rising water table in some cities such as London. The total installed capacity in the UK is then $2.91 \mathrm{MWt}$ and annual use of $20.72 \mathrm{TJ}$ of which $0.63 \mathrm{MWt}$ and $2.73 \mathrm{TJ}$ is due to geothermal heat pumps. The historic Roman spa at Bath is being renovated and will be open to the public in 2001 using the naturally occurring thermal springs for bathing.

\section{Commonwealth of Independent States}

Armenia: Since Armenia does not have any considerable fossil fuel resources and little hydro-electric potential it has become necessary to assess the geothermal resources of the country, B adalyan (2000) High heat flow values of 38 to $157 \mathrm{~mW} / \mathrm{m}^{2}$. ha ve been estimated from 90 locations about the country. The highest numbers were measured in the central part of the country where thermal springs occur. It is found that a substantial part of the heat flow anomaly is caused by local heat sources at shallow depth. Silica geothermometer estimates of reservoir temperatures range from $40^{\circ} \mathrm{C}$ to $160^{\circ} \mathrm{C}$. The eastern volcanic belt is thought to be the main area of geothermal potential where both dry and hydrothermal resources are expected. 


\section{Lund and Freeston}

Belarus: Although there is no paper at this conference, it worth recording that there is geothermal energy potential, particular for low temperature use Zui and Levashkevich (1999). There are no known high enthalpy fields but temperatures up to $110^{\circ} \mathrm{C}$ at depths up to $5 \mathrm{~km}$ in the areas known as the Brest depression and the Pripyat Trough in the south east of the country have been measured. A number of shallow and deep boreholes have been drilled by drilling companies which has enabled temperature logs and heat flow measurements to be made.

Georgia: Buchachdize et al. (2000) reviews the status and future use of geothermal fluids in Georgia. In the South Caucasus and in particular Georgia, there is intensive use of geothermal energy. As of 1998 the confirmed total reserves are $90,000 \mathrm{~m}^{3} /$ day which has a heat potential of 500,000 tonnes of equivalent fuel (TEF) annually. The field at Tbilisi, the capital of Georgia, is described as an example of the efficient use of energy and demonstrates that geothermal is cheaper and environmentally friendly for these conditions. The tables indicate that there is $350 \mathrm{MWt}$ installed with an annual energy use of $9,986 \mathrm{TJ}$; however, this figure was reduced as the former numbers were based on a discharge temperature of $25^{\circ} \mathrm{C}$ for all installations giving the difference between inlet and outlet of as high as $83^{\circ} \mathrm{C}$. Using instead a $40^{\circ} \mathrm{C}$ temperature change between inlet and outlet and a capacity factor of 0.8 , a rounded figure of $250 \mathrm{MWt}$ and 6,307 TJ/yr are used in this report summary. The maximum flow rate was also revised to $894 \mathrm{~kg} / \mathrm{s}$. In the period 1995-1999, 224 man years of effort and 1 million US\$ have been spent from mainly private funds.

Russia: Space heating (110 MWt) and greenhouse heating (160 MWt) dominate the direct-use scene in Russia, Kononov et al. (2000). Six towns and a number of settlements in the Northern Caucasus and Kamchatka, with a total population of about 220,000 , use geothermal energy for space and district heating. Several greenhouses with a total area of $465,000 \mathrm{~m}^{2}$ in the same area also geothermal fluids for heating. Besides Kamchatka and Northern Caucasus, the Western Siberian plate is a promising region for direct use applications. The aquifers located down to $3 \mathrm{~km}$, in this region have a high hydrostatic pressure, temperatures of $35-75^{\circ} \mathrm{C}$ and capable of producing about 180 $\mathrm{m}^{3} / \mathrm{s}$. These waters serve some small settlements for space heating and on a small scale are used to assist in the recovery of oil, extraction of iodine and bromide and for fish farming. The region is rich in natural gas which has limited the geothermal development. Heat pumps are at an early stage of development in Russia. An experimental facility in early 1999 was conducted in the Philippovo settlement of Yaroslavl district. The heat source is supplying $5-6^{\circ} \mathrm{C}$ to eight heat pumps which are heating the water up to $60^{\circ} \mathrm{C}$ supplying a 160 -pupil school building. An aquatic park and water heating using heat pumps is planned in Moscow. Geothermal R\& D is carried out in 14 cities of Russia where research centers unite the laboratories from 26 scientific institutes, 3 universities and 5 project bureaus. The Russian Academy of Sciences coordinates this research. The paper by Povarov (2000) adds information and detail of the country resources also mentions over a hundred heat pump applications in Siberia and Kamchatka is made but no details are given
Ukraine: Shuchkov, A. et al. (2000) discuss the possibility of utilizing the geothermal fluids discovered in a number of regions across the Ukraine. It is estimated that the commercially viable resources are about 20 to 30 million cu.m/day of waters with temperatures higher than $60^{\circ} \mathrm{C}$. The major emphasis appears to be on co-generation plants and mention is made of the use of fluid for the supply of heat to residential, industrial and agricultural buildings on a small scale within the range 0.5 to 6 MWt Some estimates of cost are included. A geothermal heating system in the range 1.2 to $6 \mathrm{MWt}$ range, would cost installed from 270 USD to 700 USD for $1 \mathrm{~kW}$ of installed power. The output cost for the same range is estimated at 16 USD to 26 USD for $1 \mathrm{MWh}$ of energy, including all costs. Sensitivity of the numbers to fluid temperature and scale of project is demonstrated.

\section{Oceania}

Australia: Burns et al. (2000) report on Hydrothermal Power production centered in the great Artesian basin serving local communities. The basin in its lower part has permeable sediments, which are the intake beds for surface waters in a humid part of Queensland. The water moves slowly westward for 1500 to $1600 \mathrm{~km}$ and after about 2 million years emerges naturally in mound springs in the desert. About half of the natural recharge is tapped by 3,100 flowing artesian bores and over 35,000 non-flowing. In some regions the water at the surface reaches $100^{\circ} \mathrm{C}$. For pastoral reasons the water is cooled and distributed by bore drains which are often tens of kilometers long, and may reach $90 \mathrm{~km}$. Small homemade power plants used bore pressures to drive simple turbines to produce electricity for homesteads. They gradually became obsolete and only 20 or so survive.

Two small ORC power plants are currently in operation which were first reported in Burns et al. (1995). These are at Mulka $(10 \mathrm{kWe})$ in South Australia and Birdsville Queensland. (39 $\mathrm{kWe}$ ). They both use fluid from old wells which produce water from $1200-1300 \mathrm{~m}$. Both plants have undergone major refurbishment since first reported.

Hydrothermal direct use continues in the Otway Basin of western Victoria, in a district heating system fully described in Burns et al. (1995). It uses $65 \mathrm{l} / \mathrm{s}$ of $58^{\circ} \mathrm{C}$ water from $1400 \mathrm{~m}$ and its current annual energy use is $271.2 \mathrm{TJ} / \mathrm{yr}$. In addition, the system supports a $2000 \mathrm{~m}^{3}$ municipal pool giving a total energy use for the Portland system of $293.8 \mathrm{TJ} / \mathrm{yr}$. There are numerous hot water pools around Australia developed for bathing by local government and tourist resorts or undeveloped, which draw water from natural hot springs but no information on heat production is available. A new development to build a hot water spa on the Mornington peninsular on the eastern part of the $\mathrm{O}$ tway Basin, was approved in 1999 . It will use $50^{\circ} \mathrm{C}$ water fro $\mathrm{m}$ a depth of $534 \mathrm{~m}$. The paper plant near Traralgon in the Gi ppsland Basin of Victoria, reported by Burns et al. (1995) whi ch used $68^{\circ} \mathrm{C}$ water from two wells $600 \mathrm{~m}$ deep has ceased operation because of dewatering of the region due to the expansion of brown coal mining operations. 
Ground and water source heat pumps have been widely adopted throughout Australia for air conditioning with at least 2000 installations in place and an estimated market expansion by more than $50 \%$ per annum including systems for heating commercial quantities of hot water and systems to dry fruits and vegetables. Several large systems are mentioned in Burns et al. (2000) but unfortunately no quantitative information is available. Research on raising the COP for heat pumps is underway at Melbourne and the Australian National Universities in collaboration with the Advanced Engineering Center for Manufacturing, by using paraffin wax as a phase change material on either side of the pump within the geothermal system.

New Zealand: Since the last update in Thain and Freeston (1995) there have been only minor changes in the New Zealand direct-use scene. The major direct user continues to be the Tasman Pulp and Paper Mill operation at Kawerau. With an installed capacity of $210 \mathrm{MWt}$ and an annual energy use of $5,500 \mathrm{TJ} / \mathrm{yr}$, (Thain and Dunstall, 2000) uses geothermal fluids to generate clean process steam for paper drying, a source of heat in evaporators, timber drying and electricity generation. Geothermal condensate previously discharged to the Tawarewa river is now collected, cleaned and used in power and liquor recovery boilers. Also on site is a timber drying plant and a green house of $5,250 \mathrm{~m}^{2}$. Taupo Lucerne plant which used steam initially, has been converted to using reinjection hot water from the Ohaaki electric power system. The Wairakei prawn farm was also discussed in the 1995 paper but has since been converted for heating its 5.8 hectares of ponds with $130^{\circ} \mathrm{C}$ hot water from the Wairakei reinjection system. This farm has a capacity of $18.6 \mathrm{MWt}$ and an annual utilization of $363 \mathrm{TJ} / \mathrm{yr}$. Other uses of geothermal fluids are scattered about the central North Island but industrial use of geothermal heat is not extensive. The largest concentration of small direct heat users is in Rotorua where there is a long history of use. A management plan for the resource has been put in place which has proved to be a success. The bore users have some 150 small wells representing a capacity of $>22 \mathrm{MWt}$ and an annual utilization of $694 \mathrm{TJ} / \mathrm{yr}$.

\section{ENERGY SAVINGS}

Using geothermal energy, obviously replaces the use of other forms of energy, especially fossil fuels. The benefits thus accrued are for many countries, less dependence on imported fuels, and for all, elimination of pollutants such as particulates and greenhouses gases. An attempt is made here to quantify these savings of fossil fuels using a 0.35 efficiency factor if the competing energy is used to produce electricity, and 0.70 if it is used directly to produce heat such as in a furnace.

Using the $162,009 \mathrm{TJ} / \mathrm{yr}$ of energy produced, estimating that a barrel of fuel oil contains $6.06 \times 10^{9} \mathrm{~J}$, and that the fuel is used to produce replacement electricity, the savings would be 76.4 million barrels of oil or 11.4 million tonnes of oil annually. If the oil were used directly to produce energy by burning, then these values would be reduced by half. The actual saving is most likely somewhere in between these two values.

Using figures developed by Lawrence Livermore Laboratories for the U.S. Department of Energy, the following carbon savings would be realized. If electricity were produced, then the carbon saving would by 14.65 tonnes/TJ from natural gas, 62.6 tonnes/TJ from oil or 72.7 tonnes/TJ from coal. This then produces a savings in carbon production of 2.37 million tonnes, 10.14 million tonnes or 11.78 million tonnes respectively. If the energy were produced by burning these fuels, the carbon saving would be half these values. Again the actual saving would be somewhere in between these sets of values and would include a mix of fossil fuels.

\section{CONCLUDING REMARKS}

As in 1995, some countries stand out as major users of geothermal fluids for direct-use, and in most countries the development has been slow. This is not surprising since the price of oil and natural gas during the past five years has been a major competitor to development of geothermal projects. However, many countries have been doing the necessary ground work by conducting an inventory and quantifying their resources in preparation for development when fossil fuel prices increase. We are also seeing many newcomers to the geothermal directuse club - which we welcome - and hope to see more in the future. At the writing of these report, we are already seeing the cost of crude oil triple over the past year. In addition, the downturn in the economy of newly independent countries and in SE Asia have also stymied development in both the electric generation and direct-use fields. An important task for all of us, is to get the word out about the uses of geothermal energy and its many environmental benefits.

The country update reports used in this summary often had key data and explanation lacking, even though it was requested. In other cases, the data appeared to be in error or misreported. The authors hope to clarify these discrepancies at the World Geothermal Congress in Japan and then issue a final report later in the year, to be published in Geothermics Journal. We do not expect to see any set of numbers change significantly.

Even with these discrepancies, which we tried to correct in part, the preparation of this report has been useful if only to demonstrate that the use of low- to moderate-temperature geothermal resources for direct-use, given the right environment, is viable and economic. As oil and gas supplies dwindle and increase in price, the use of geothermal energy will become an even more economic viable alternative source of energy.

\section{ACKNOWLEDGMENTS}

The authors wish to thank the U.S. Department of Energy for providing support to prepare this report. We would also like to thank Tonya L. Boyd and Donna Gibson of the Geo-Heat Center staff for assisting in the preparation of the final document. We gratefully acknowledge those authors that submitted country update reports and completed the tables. This paper would not have been possible without their cooperation.

\section{REFERENCES}

Adajar, J.C., (1999). Manito Livelihood project. Proceedings of the Workshop - International Geothermal Days - Oregon 1999, Geo-Heat Center, Klamath Falls, OR, pp. 147-152. 


\section{Lund and Freeston}

Aires-Barros, L., and J. Marques, (2000). Portugal Country Update, Proceedings of the World Geothermal Congress 2000, Japan.

Alfara, C., Bernal, N., Ramirez, G., and R. Escovar, (2000). Columbia Country Update, Proceedings of the World Geothermal Congress 2000, Japan.

Allen, D. M, Ghomshei, M. M., Sadler-Brown, T. L., Dakin, A., and D. Holtz, (2000). The Current Status of Geothermal Exploration and Development in Canada, Proceeding of the World Geothermal Congress 2000, Japan.

Alm, P., and L. Bjelm, (1995). Sweden - Country Update, Proceedings of the World Geothermal Congress 1995, Florence, Vol. 1, International Geothermal Association, Pisa, pp. 327-8.

Árpási, M., Kovács, L., and G. Szabo, (2000). Geothermal Development in Hungary - Country Update Report 1995-199 9, Proceedings of the World Geothermal Congress 2000, Japa n.

Axelsson, G., and Zhilin Dong., (2000). The Tanggu Geothermal Reservoir (Tianjin, China). Geothermics, vol 27 no 3 pp 271-294.

Badalyan, M., (2000). Geothermal Features of Armenia: A Country Update. Proceedings of the World Geothermal Congress 2000, Japan.

Bakht, M. S., (2000). An Overview of Geothermal Resources of Pakistan, Proceedings of the World Geothermal Congress 2000, Japan.

Batchelor, T., (1995). International Geothermal Association web page, UK country update.

Batik, H., Kocak, A., Akkus, I., Simsek, S., Mertoglu, O., Do kuz, I., and N. Bakir., (2000). Geothermal Energy Utilization in Turkey - Present Geothermal Situation and Projections. $P r$ oceedings of the World Geothermal Congress, Japan.

Berckmans, A., and N. Vandenberghe, (1998). Use and Potential of Geothermal Energy in Belgium, Geothermics, Vol. 27, No. 2, Pergamon, Elsevier Science, Inc., New York, pp. 2 $35-42$.

Bojadgieva, K., Hristov, H., Hristov, V., and A. Benderev, (2000). Status of Geothermal Energy in Bulgaria, Proceedings of the World Geothermal Congress 2000, Japan.

Ben Dhia, H. and S. Bouri, (1995). Overview of Geothermal Activities in Tunisia. Proceedings of World Geothermal Congress, Florence Italy, May pp 341-344.

Buachidze, G., Vardigorelli, O., and N. Tsertsvadze, (2000). Country Update from Georgia, Proceedings of the World Geothermal Congress 2000, Japan.
Burns, K. L., Creelman, R. A., Buckingham, N. W., and H. J. Harrington, (1995). Geothermal Development in Australia, $P$ roceedings of the World Geothermal Congress 1995, Florence, Italy, pp. 45-50.

Burns, K.L., Weber, C., Perry, J. and H. J Harrington, (2000). Status of the Geothermal Industry in Australia. Proceedings of the World Geothermal Congress, Japan.

Cai, Y., (2000). The Technical Progress of Geothermal Energy for Space Heating in Tianjin. Proceedings of the World Geothermal Congress, Japan.

Cappetti, G., Passaleva, G., and F. Sabatelli, (2000). Italy Country Update Report 1995-1999, Proceedings of the World Geothermal Congress 2000, Japan.

Carella, R., and C. Sommaruga, (2000). Geothermal Residential and Agribusiness Heating in Italy, Proceedings of the World Geothermal Congress 2000, Japan.

Casimiro, E., and E. Pastrana, (1996). Wood and Fruit Drying in the Los Azufres Geothermal Field, Mexico, Transactions of the Geothermal Resources Council, Vol 20, Davis, CA, pp. 56 3-566.

Castillo, G. E., and R. M. Salgado, (2000). Honduras Country Update Paper, Proceedings of the World Geothermal Congress 2000, Japan.

Chandrasekharem, D., (2000). Geothermal Energy Resources of India: Country Update. Proceedings of the World Geothermal Congress, Japan.

Charusiri, P., Chaturongkawanich, S., Takashima, I., Kosuwan, S., Won-in, K. and N. N. Cat, (2000). Application of Geothermal Resources of Thailand, Vietnam, and Myanmar to Tectonic Settings. Proceedings of the World Geothermal Congress, Japan.

Chua, S. E., Abito, G. F. and M. C. Berbano, (1996). Geothermal Non-power Application: The PNOC Experience. Transactions of the Geothermal Resources Council, Vol 20, Sept/ Oct., Davis, CA, pp 65-71

Cohut, I. and C. Bendea, (2000). Romania Update Report for 1995-1999, Proceedings of the World Geothermal Congress 2000, Japan.

Curtis, R., (2000). GeoSciences Ltd., Falmouth, Great Britain, personal communication (22 Feb.)

Desplan, A., (2000). BRGM, Orleans, France, personal communications (29 Feb.).

Dimitrov, K., Gorgieva, M., and K. Popovski, (2000). Geothermal Energy Resources and Their Use in Republic of Macedonia, Proceedings of the World Geothermal Congress 2000, Japan. 
Fauzi, A., Bahri, S. and H. Akuanbatin., (2000). Geothermal Development in Indonesia: an Overview of Industry Status and Future Growth. Proceedings of the World Geothermal Congress, Japan.

Fendek, M., and J. Franko, (2000). Country Update of the Slovak Republic, Proceedings of the World Geothermal Congress 2000, Japan

Fotouhi, M., and Y. Noorollahi, (2000). Updated Geothermal Activities in Iran, Proceedings of the World Geothermal Congress 2000, Japan.

Frasheri, A., (2000). The Sources of Geothermal Energy in Albania, Proceedings of the World Geothermal Congress 2000, Japan.

Freeston, D. H., (1995). Direct Uses of Geothermal Energy 1995 (preliminary review), Proceedings of the World Geothermal Congress 1995, Florence, International Geothermal Association, pp. 15-25.

Freeston, D. H. (1996). Direct Uses of Geothermal Energy 1995, Geothermics 25, Pergamon, England, April, pp. 189-21 4

Fytikas, M., Andritsos, N., Karydakis, G., Kolios, N., Mendri nos, D., and M. Papachristou, (2000). Geothermal Exploratio $\mathrm{n}$ and Development Activities in Greece During 1995-1999, $P$ roceedings of the World Geothermal Congress 2000, Japan.

Goldbrunner, J., (1999). Austrian Geothermal Update (General Abstract and Tables), sent to Geo-Heat Center, Klamath Falls, OR (6 March).

Greitzer, Y. and D. Levitte, (2000). Geothermal Update Report from Israel 1999, Proceedings of the World Geothermal Congress, Japan.

Hochstein, M.P., Temu, E.P. and C. M. A. Moshy, (2000). Geothermal Resources of Tanzania. Proceedings of the World Geothermal Congress, Japan.

Huang, S., (2000). Looking Back and Ahead for Geothermal Energy Development in China. Proceedings of the World Geothermal Congress, Japan.

Huttrer, G. W., (2000). Geothermal Activity Status in the Volcanic Caribbean Islands, Proceeding of the World Geothermal Congress 2000, Japan.

Huttrer, G. W., (2000). Geothermal Management Co., Colorado, personal communication (Feb.)

Isabirye, E., (2000). Geothermal Energy in the Development of Uganda. Proceedings of the World Geothermal Congress, Ja pan

Jelić, K., Čubrić, S., Pavičić, H., and R. Bošnjak, (2000). Geothermal Energy Potential and Utilization in the Republic of Croatia, Proceedings of the World Geothermal Congress 2000, Japan.
Jessop, A., (1995). Geothermal Energy from Old Mines at Springhill, Nova Scotia, Canada, Proceedings of the World Geothermal Congress 1995, Florence, Italy, International Geothermal Association, Vol. 1, pp. 463-8.

Kane, D., (2000). Caneta Research Co., Ontario, personal communication (10 Feb.).

Karunungan, V. M. and R. A. Requejo, (2000). Update on Geothermal Development in the Philippines, Proceedings of the World Geothermal Congress 2000. Japan

Kepinska, B., Bujakowski, W., and R. Ney, (2000). Geothermal Energy Country Update Report from Poland, Proceedings of the World Geothermal Congress 2000, Japan.

Kocak, A., (2000). Situation of Geothermal Energy in Turkey. Proceedings of the World Geothermal Congress, Japan.

Kononov, V., Polyak, B., and B. Kozlov, (2000). Geothermal Development in Russia: Country update report 1995-1999. P roceedings of the World Geothermal Congress, Japan.

Kralj, P., and D. Rajver, (2000). State-of-the-Art of Geothermal Energy Use in Slovenia, Proceeding of the World Geothermal Congress 2000, Japan.

Kukkonen, I. T., (2000). Geothermal Energy in Finland, Proc eedings of the World Geothermal Congress 2000, Japan.

LaPlaige, P., Jaudin, F., and J. Demange, (2000). The French Geothermal Experience - Review and Perspectives, Proceedings of the World Geothermal Congress 2000, Japan

Liao, Z, (1997). Energy and its Utilization in China, Transact ions of the Geothermal Resources Council, Vol 21., Davis, C A, pp. 375-377.

Lowenstern, J., (1996). USGS/Eritrean Team Assessment of Geothermal Potential of Eritrean Volcanic Center. IGA News Quarterly, No 25 April-June pp6-7.

Lund, J. W., (1990). Geothermal Spas in Czechoslovakia, Ge o-Heat Center Quarterly Bulletin, Vol. 12, No. 2 (Winter), Klamath Falls, OR, pp. 20-24.

Lund, J. W., and T. L. Boyd, (2000). Geothermal Direct-Use in the United States Update: 1995-1999, Proceedings of the World Geothermal Congress 2000, Japan.

Mahler, A., (2000). Geothermal Plant with Efficient Absorption Heat Pumps Driven by Incineration CHP Plant. Country Update Denmark, Proceedings of the World Geothermal Congress 2000, Japan.

Melaku, M., Thompson, S. and T Mills., (1995). Geothermal Heat for Soil Sterilization. Proceedings of the World Geothermal Congress, Florence, Italy, May, pp 2281-2284.

Merida, L., (1999). Curing Blocks and Drying Fruit in Guatemala, Geo-Heat Center Quarterly Bulletin, Vol. 20, No. 4 (December), Klamath Falls, OR, pp. 13-18. 


\section{Lund and Freeston}

Milivojevic, M., and M. Martinovic, (2000). Geothermal Energy Possibilities, Exploration and Future Prospects in Serbia, Proceedings of the World Geothermal Congress 2000, Japan.

Mohamed, M.B., (1997). Agricultural Geothermal Utilization in Kebili Region, Tunisia. Reports of the United Nations University, Geothermal Training Programme, , Number 2, R eykjavik, Iceland, pp. 27-56.

Mwangi, M., (2000). Country update report for Kenya. Proc eedings of the World Geothermal Congress, Japan.

Povarov, O. A., (2000). Geothermal Power Engineering in Russia - Today, Proceedings of the World Geothermal Congress 2000, Japan.

Pesce, A. H., (2000). Argentina Country Update, Proceedings of the World Geothermal Congress 2000, Japan.

Quijano-Leon, J. L. and L. C. A. Gutierrez-Negrin, (2000). Geothermal Projection and Development Plans in Mexico, Pr oceeding of the World Geothermal Congress 2000, Japan.

Rafferty, K., (1999). Aquaculture in the Imperial Valley - A Geothermal Success Story, Geo-Heat Center Quarterly Bulletin, Vol. 20, No. 1 (March), Klamath Falls, OR, pp. 1-4.

Ragnarsson, A., (2000). Geothermal Development in Iceland 1995-1999, Proceedings of the World Geothermal Congress 2000, Japan.

Ramingwong, T., Lertsrimongkol, S., Asnachinda, P. and S. P raserdvigai, (2000). Update on Thailand Geothermal Energy Research and Development. Proceedings of the World Geothermal Congress, Japan.

Ranjit, M., (2000). Geothermal energy update of Nepal. Pro ceedings of the World Geothermal Congress, Japan.

Rangel, M. E. R., (1998). Mushroom Growing Projects at the Los Humeros, Mexico Geothermal Field, Geo-Heat Center Quarterly Bulletin, Vol. 19, No. 4, Klamath Falls, OR, pp. 14 -16 .

Rimi, A., (2000). First Assessment of Geothermal Resources in Morocco. Proceedings of the World Geothermal Congress, J apan.

Rybach, L, and B. Sanner (1999). Ground-Source Heat Pump Systems - The European Experience, Proceedings of the 1999 Workshops - International Geothermal Days - Oregon 1999, Klamath Falls, OR, pp. 159-170.

Rybach, L., Brunner, M., and H. Gorhan, (2000). Swiss Geothermal Update 1995-2000, Proceedings of the World Geothermal Congress 2000, Japan.

Sadlier-Brown, T. L., (2000). Canadian Geothermal Energy Association, Vancouver, personal communication (10 February).
Sanner, B., and G. Hellström, (1998). Examples for Underground Thermal Energy Storage with Borehole Heat Exchangers in Central and Northern Europe, Newsletter IEA Heat Pump Center, Vol. 16, No. 2., Sittard, Netherlands, pp. 25-7.

Sarolkar, P. B. and U.L. Pitale. (2000). The Possibilities of Utilization of Heat from Tattapani Geothermal Field, India. $P$ roceedings of the World Geothermal Congress, Japan.

Schellschmidt, R., Clauser, C., and B. Sanner, (2000). Geothermal Energy Use in Germany at the Turn of the Millennium, Proceedings of the World Geothermal Congress 2000, Japan.

Sekioka, M. and M. Yoshii, (2000). Country Update Report of Direct Uses in Japan. . Proceedings of the World Geothermal Congress, Japan.

Shurchkov, A., Zabarny, G. , Razakov, A. and A. Zadorozhna. (2000). Promising Undiscovered Thermal Waters Potential of Ukraine Planned for Commercial Utilization. Proceedings of the World Geothermal Congress, Japan.

Smith, M., (2000). Southampton Energy Scheme, Proceedings of the World Geothermal Congress 2000, Japan

Stibitz, M., (1999). GEOMEDIA Ltd., Prague, Czech Republic, personal communication in a draft paper for the World Geothermal Congress 2000 (15 February).

Sudarman, S. , Suroto, Pudyastuti, K. and S. Aspiyo. (2000). Geothermal Development Progress in Indonesia: Country Update 1995-2000. Proceedings of the World Geothermal Congress, Japan.

Suveizdis, P., Rasteniene, V., and F. Zinevicius, (2000). Geothermal Potential of Lithuania and Outlook of its Utilization, Proceedings of the World Geothermal Congress 2000, Japan.

Swarieh, A., (2000). Geothermal Energy Resources in Jordan, Country Update Report. Proceedings of the World Geothermal Congress, Japan.

Teklemariam, K., Beyene, M., Amdeberhan, A and Z Gebreg ziabher, (2000). Geothermal Development in Ethiopia. Proc eedings of World Geothermal Congress, Japan.

Terceros, Z. D., (2000). State of the Geothermal Resources in Bolivia, Proceedings of the World Geothermal Congress 2000, Japan.

Thain, I., and D. H. Freeston, (1995). 1990-1995 Update Report on the Existing and Planned Utilisation of Geothermal Energy for Electricity Generation and Direct Heat Use in New Zealand, Proceedings of the World Geothermal Congress 1999, Florence, Italy, pp. 283-288. 
Thain, I. and M. Dunstall., (2000). 1995-2000 Update Report on the Existing and Planned Use of Geothermal Energy for Electricity Generation and Direct Use in New Zealand. Proce edings of the World Geothermal Congress, Japan.

Urbani, F., (1999). Geothermal Resources in the El Pilar Region, IGA News, No. 30, Pisa, Italy, (Oct.-Dec.), pp. 11.

Vandenberghe, N.,(1999 and 2000). K. U. Leuven, Department of Earth Sciences, Leuven, Belgium, personal communication (11 January and 14 February).

Walter, F., (1995). The Status of Geothermal Energy in the Netherlands, Proceedings of the World Geothermal Congress 1995, Vol. 1, Florence, International Geothermal Association, Pisa, pp. 279-281.

Wang, L. and N. Wang. (2000a). Review of the Geothermal Development and Utilization for the past Two Decades and Sustainability in Hebei Province, P.r. of China. Proceedings of the World Geothermal Congress, Japan.

Wang, L. and N. Wang. (2000b). Geological Characteristics and Development Planning in Xiong County Geothermal Fiel d, Hebei Province, P.R.China. Proceedings of the World Geothermal Congress, Japan.
Yum, B.W. (2000). The Present Status of Korean Geothermal Research and Investigation. Proceedings of the World Geothermal Congress, Japan.

Zhang, Z., Wang J., Ren, X., Liu, S. and H. Zhu, (2000). The State of the Art and Future Development of Geothermal Energy in China. Country Update Report for the Period 1996-2000. Proceedings of World Geothermal Congress, Japan.

Zhu, J., (1999). Geothermal Utilization and Development in China, Proceedings of the Workshop - International Geothermal Days - Oregon 1999, Geo-Heat Center, Klamath Falls, OR pp. 157-160.

Zui, V.I. and V.G. Levashkevich, (1999). Preliminary Estimates of Geothermal Potential of Belarus. Proceeding of the Workshop - International Geothermal Days - Oregon 1999, G eo-Heat Center, Klamath Falls, OR pp 185-189

Zuniga, A, and M. Median, (2000). Nicaragua Country Updat e, Proceedings of the World Geothermal Congress 2000, Japa n. 